\title{
Multi-objective optimization in titanium powder mixed electrical discharge machining process parameters for die steels
}

Phan Nguyen Huu ( $\nabla$ phanktcn@gmail.com )

\section{Original Article}

Keywords: Deng's similarity-based method, Multi-criteria decision making, Multiobjective optimization, Powder mixed electrical discharge machining

Posted Date: April 15th, 2020

DOI: https://doi.org/10.21203/rs.3.rs-22417/v1

License: (c) (1) This work is licensed under a Creative Commons Attribution 4.0 International License. Read Full License

Version of Record: A version of this preprint was published at Alexandria Engineering Journal on December 1st, 2020. See the published version at https://doi.org/10.1016/j.aej.2020.07.012. 


\title{
Multi-objective optimization in titanium powder mixed electrical discharge machining process parameters for die steels
}

\author{
Phan Nguyen Huu* \\ Hanoi University of Industry, No. 298, Cau Dien Street, Bac Tu Liem District, Hanoi, Vietnam \\ *Corresponding author E-mail: phanktcn@gmail.com or nguyenhuuphan@haui.edu.vn
}

\begin{abstract}
:
In this paper, we propose a viable optimal solution for achieving multi-objective optimization in powder mixed electrical discharge machining (PMEDM) process parameters, using titanium powder. Taguchi-AHP-Deng's method is used to solve the multi-criteria decision making (MCDM) problem for this technology. The process parameters selected are workpiece material, electrode material, electrode polarity, pulse on time (Ton), pulse off time (Tof), current (I), and powder concentration. The material removal rate (MRR), tool wear rate (TWR), surface roughness (SR), hardness surface (HV), and white layer thickness (WLT) were determined simultaneously. The results showed that the optimal material for the workpiece is SKD11 die steel; the optimal material for the electrode is Gr; and the polarity of the electrode should be positive. The optimal values for the other process parameters were determined to be Ton $=20 \mu \mathrm{s}$, Tof $=57 \mu \mathrm{s}$, and I $=8 \mathrm{~A}$, and that for the powder concentration was $10 \mathrm{~g} / \mathrm{l}$. The quality criteria for the optimal process parameters were determined to be MRR $=59.669 \mathrm{~mm}^{3} / \mathrm{min}$, TWR $=14.073 \mathrm{~mm}^{3} / \mathrm{min}, \mathrm{SR}=4.45 \mu \mathrm{m}, \mathrm{HV}$ $=907.64 \mathrm{HV}$ and $\mathrm{WLT}=8.56 \mu \mathrm{m}$. The results were verified through experiments, which revealed a good accuracy (error $\approx 11.67 \%$ ). The white-layer formation on the machined surface was reduced using titanium powder-based PMEDM for die steel at the optimal conditions. The results showed that Deng's similarity method is the most suitable for MCDM in PMEDM using titanium powder.
\end{abstract}

Keywords: Deng's similarity-based method; Multi-criteria decision making; Multiobjective optimization; Powder mixed electrical discharge machining.

\section{Introduction}

Powder mixed electrical discharge machining (PMEDM) is a highly efficient technology that improves the productivity and quality of complex machined surfaces made from hard materials. At present, the primary solution for improving the processing efficiency of PMEDM is the optimization of process parameters. Among these optimization methods, MCDM has been gaining considerable attention [1]. PMEDM involves several process parameters having a broad level of variation, and there exist several noise factors related to the machining characteristics. Owing to this complexity, it is difficult to solve the problem of MCDM in PMEDM. The experimental process entails significant expenses, and the accuracy of the results is limited. In addition, the calculations for the weight of the quality criteria selected in the MCDM are very complex. Recently, several solutions have been proposed to overcome these limitations, and the results of these studies have contributed to improving the applicability of PMEDM.

The main research directions in EDM in general and PMEDM in particular include increased MRR, decreased TWR and machined surface quality is improved. Recent research in this area has shown that the experimental method is still the preferred method of studying these techniques. Hence, the number of process parameters, the number of experiments in the experiment matrix, and the number of quality criteria that can be calculated using MCDM method are interesting areas that have yet to be explored. Exploring these areas is important because it has a direct impact on the effectiveness of results of optimization methods and the cost of the research process. The Taguchi method is known to be an optimum solution that fits a wide variety of machining methods, especially the methods with machining mechanisms that are not well understood, and the quality criteria are affected by noises. EDM and PMEDM are examples of such solutions. 
Taguchi method can study the largest number of process parameters, but the number of experiments that can be studied in this method is the smallest. However, this is the only method that can optimize single criterion; hence, certain recent studies have proposed using the Taguchi method with the incorporation of several MCDM methods, such as GRA, TOPSIS, and PCA, to optimize the process parameters in EDM and PMEDM [2].

In this study, we perform multi-objective optimization of a process parameter in PMEDM using titanium powder for die steels. Taguchi-AHP-Deng's method is used for MCDM to achieve this. The results obtained in this study were analysed and compared with those of other multi-objective methods, such as GRA, PSI, and TOPSIS, to show the suitability of Taguchi-AHP-Deng's method for this problem. The quality of the machined surface under the optimum conditions was also analysed to investigate the effectiveness of mixing titanium powder with the dielectric during the machining of EDM. Furthermore, the effectiveness of the solution was analysed and evaluated empirically.

\section{Literature review}

Taguchi-GRA has been used for multi-objective optimization in EDM parameter for Ti $6 \mathrm{Al}-4 \mathrm{~V}$ material [3]. The set of optimal parameters is determined by ANOVA for the ranking index value and compared to the optimal result by ranking index. The optimum efficiency was increased to $8.3 \%$ with the $\mathrm{S} / \mathrm{N}$ of the ranking index value. The results showed that the MRR was increased by $87.3 \%$, and EWR and SR were reduced by $25.7 \%$ and $18.9 \%$, respectively. The weight of the quality criteria is determined experimentally. Multi-objective optimization in micro-EDM parameter for $\mathrm{Cp}$ titanium by Taguchi-GRA is performed in [4]. In this work, the authors compare the optimal result by the ranking index with its of $\mathrm{S} / \mathrm{N}$ of the ranking index, and find that the optimum efficiency with $\mathrm{S} / \mathrm{N}$ is higher than by $13.64 \%$. The process parameters in PMEDM using $\mathrm{C}$ and $\mathrm{Al}_{2} \mathrm{O}_{3}$ powder were optimized by Taguchi-GRA in [5]. In this work, the weight of SR and HV were determined experimentally $\left(\mathrm{W}_{\mathrm{SR}}=\mathrm{W}_{\mathrm{HV}}=0.5\right)$. For the mean value of the ranking index, ANOVA method was used to evaluate the effect of the process parameters on the optimal results. However, the optimal process parameters are determined only by the ranking index. Their results show that the quality criterion in PMEDM improved by $46.52 \%$. In [6], using Taguchi-GRA to solve the MCDM, the optimal parameters in PMEDM using SiC powder determined by ranking index and $\mathrm{S} / \mathrm{N}$ of the ranking index were shown to be different.

A multi-objective optimization of EDM process parameters for AISI D2 steel was performed using TOPSIS [7]. The results indicated that $\mathrm{S} / \mathrm{N}$ of the ranking index determined the optimal set of process parameters, and were different from those of the index ranking. The voltage represents the difference between two methods of determining the optimal process parameters. It is also the most influential parameter for the optimal criteria, and thus has a significant effect on the optimization results. The authors of the aforementioned study also found that compared with the result of the ranking index, the optimum efficiency of $\mathrm{S} / \mathrm{N}$ of the ranking index was improved by $70.3 \%$. Multi-objective optimization in EDM process parameters using the Taguchi-TOPSIS method was has also been performed [8-10]. Therein, ANOVA of the ranking index mean was performed to determine the influence of the process parameters on the optimal efficiency; however, S/N of the ranking index was not performed. RSM combined with TOPSIS for multi-objective optimization in EDM process parameter for Ti-6Al-4V material was used in [11]. Triangular fuzzy has been used to determine the weight of the quality criteria. The ranking index determines the optimal process parameters. More experiments have been performed using this combination than using the Taguchi method. WLT, SCD, SR, and OC in EDM for AISI P20 have been studied using MCDM with RSM-TOPSIS [12]. The optimal process parameter was determined using the ANOVA of the ranking index mean, and its results coincided with its ranking index. The quality characteristics in EDM are best at the optimal values of the process parameters, which shows that this is the best solution for the problem. Results obtained using the PSI and TOPSIS methods have been compared through 
MCDM in EDM for EN31 steel [13]. Based on the optimal ranking index, these methods were shown to have the same results. This suggests that PSI is a more efficient method than TOPSIS owing to the fact that the weight of quality criteria in PSI is not calculated, making PSI simpler and shorter. Results obtained using MCDM in EDM by PSI were compared with those obtained using TOPSIS, GTMA, and WASPAS in machining processes; it was shown that PSI is the simplest method [14]. Moreover, the optimal effect of PSI is equivalent to those of other methods in some specific cases. However, PSI is not suited for MCDM of machining processing because its quality criteria have different priorities. Therefore, it is necessary to conduct further research to verify the suitability of this method for each machining process condition. A comparison between the optimal results in EDM obtained using GRA, RSM and TOPSIS, was performed in [15]; the results showed that the optimal result obtained using TOPSIS is the most accurate. The effectiveness of multi-objective optimization in the EDM process parameter for MDN 300 steel, as performed using the Taguchi-Fuzzy-GRA method, was shown to have improved by $6.45 \%$ [16]. Therein, the weighted values of the quality criteria were determined using Fuzzy logic. The optimal process parameter obtained using $\mathrm{S} / \mathrm{N}$ of the ranking index is different from that obtained using the ranking index, and the optimum efficiency is similar to that of TOPSIS. The optimal process parameter of MCDM in PMEDM using chromium powder $(<53 \mu \mathrm{m})$ for H11 steel with $\mathrm{Cu}$ electrode was determined using $\mathrm{S} / \mathrm{N}$ of the ranking index of GRA and TOPSIS methods [17]. Compared with the results obtained using the optimal ranking index, the optimal effect of S/ $\mathrm{N}$ of the ranking index was $37.21 \%$ higher with GRA and $21.33 \%$ higher with TOPSIS. Both the multi-objective optimization methods in used this study are wellsuited for the problem considered, but their effectiveness depends on the quality of the output characteristics. The effectiveness of GRA and TOPSIS was assessed according to the results of MCDM in EDM for EN31, and Taguchi method was used to design the experiments, in [18]. Therein, the results obtained using TOPSIS were better than those using GRA. In addition, a comparison between $\mathrm{S} / \mathrm{N}$ of ranking index values in TOPSIS and GRA has shown that TOPSIS yields process parameters identical to those determined using a ranking index, and that the accuracy of the optimal value is higher than it is in the GRA. Therefore, TOPSIS is the most suitable solution for this problem. A combination of Taguchi - TOPSIS methods was used to solve MCDM in EDM [19]. Therein, the SDV was used to determine the weighted values of the optimal criteria. The ranking index was used to determine the optimal process parameter, and the processing efficiency was improved with those process parameters. The Taguchi-AHP-TOPSIS method was used to achieve multi-objective optimization of EDM process parameters with CNT-infused copper electrodes [20]. Therein, $\mathrm{S} / \mathrm{N}$ of the ranking index was used to determine the optimal process parameters. The processing efficiency was notably improved for the optimum process parameters, by $14.38 \%$, and MRR was reduced by $40.31 \%$; in addition, EWR was reduced by $48.91 \%$, and SR was reduced by $172.95 \%$. MRR and TWR in EDM drilling for Al - 7075 are MCDM by Taguchi-GRA [21]. A comparison of the optimal results obtained using the ranking index with those obtained using $\mathrm{S} / \mathrm{N}$ for the ranking index has shown that the optimum efficiency of S/N is higher by $24 \%$. Moreover, MRR increased by $98.3 \%$; TWR increased by 57.3\%; and the machined-surface quality at the optimum condition was also good. The Taguchi-TOPSIS method was used to determine the optimal process parameters in the EDM by assigning the weights of the seven quality criteria (TA, OC, Cent, Cexit, MRR, TWR, SR) based on practical experience [22]. The results showed that the optimal process parameters obtained using $\mathrm{S} / \mathrm{N}$ of the ranking index were not the same as those obtained using the ranking index. The optimal result obtained using $\mathrm{S} / \mathrm{N}$ of the ranking index was significantly improved $(\sim 46.19 \%)$. The pulse off time (Tof) is a parameter that strongly influences the optimal result. Thus, the accuracy of the optimal result was strongly influenced. The Taguchi-Fuzzy-TOPSIS method was used for multiobjective optimization of EDM process parameters for 304 steel [23-24]. The optimal process parameter obtained using $\mathrm{S} / \mathrm{N}$ of ranking index was not the same as that obtained 
using the rating index. Three different parameters were analysed in the aforementioned study.

Differences in the optimum process parameters were obtained when MCDM was used in the PMEDM using Taguchi-PCA-TOPSIS [25]. GRA and TOPSIS have been shown to be effective MCDM methods in EDM, and S/N of the ranking index has been used to determine optimal parameters [26]. The results therein showed that the choice of the appropriate method would depend on the quality output criteria of the research. Compared with the GA, SA, PSO methods, the Taguchi-TOPSIS combination has been shown to have a shorter calculation time [27]. The Taguchi-TOPSIS method is a commonly used method in EDM and PMEDM, and the calculation time for the method continues to be reduced [28]. The results obtained by using this method are similar to those obtained using methods such as PSO, GA, and others. However, the results of some studies have also shown the limitations of using of TOPSIS for MCDM in this area. The limitation of using Taguchi-TOPSIS in EDM is the difference in the optimum parameters obtained using the ranking index and $\mathrm{S} / \mathrm{N}$ of ranking index [29]. Taguchi-AHP-Deng's method was proposed for determining the optimum process parameters along with simultaneous determination of seven quality criteria [30]. The results showed that Deng's method is effective for overcoming the limitations of TOPSIS. As EDM and PMEDM are very complex machining processes, optimizing the process parameters of this technology, especially its MCDM, is very difficult. MCDM studies in EDM are widely available, but research on MCDM in PMEDM is not as extensive. The optimal results in this area by incorporating Taguchi with MCDM methods are very significant.

In several studies, these combinations have been arbitrarily chosen, without considering the suitability of the Taguchi method with other methods by $\mathrm{S} / \mathrm{N}$ of ranking index. Also, the weights of the criteria in many of the works are determined by empirical research, and this has led to the effectiveness of optimized results that have a scope limited to practical applications [31]. In the multi-objective optimization problem, it is essential to determine the value of the weight of quality criteria accurately and to see that it is appropriate for practical purpose. The value of the weights can be determined by calculation or empirical method [32]. However, empirical methods often have substantial experimental costs, are time consuming, and the limited scope of the application limits scope of results. Therefore, the calculation method has been used more commonly. However, determining the value of the weights in many cases is very difficult. This is due to the conflicts between various quality criteria. Several methods have been used, such as Fuzzy Logic, Weighted entropy, SDV, AHP and where AHP is a more realistic alternative [33]. AHP is the most widely used method. This method uses pairs of comparisons between quality criteria to determine the priority of each criteria being considered. It then ranks the overall priority of each criterion. Therefore, Taguchi-Deng's method for MCDM of four quality characteristics (CS, MRR, SR, and DD) have been evaluated in EDM [34]. AHP is used to determine the weights of quality criteria, and the ranking index determines the optimal process parameter. The results have demonstrated that this is the perfect technique for the optimization. The results of analyses, given in Table 1, show that the steps taken to determine optimal process parameters and quality criteria are not uniform. The results obtained in the several previous studies (in table 1) are different, leading to differences in the optimum effect. This has shown that it is necessary to have a suitable solution to determine the weight of the quality indicators in such studies. Results need to be studied to achieve the results in [16, 34], which will facilitate the selection of optimal parameters. The optimal results of many published studies may need to be reconsidered for more accurate and scientific. Especially those that give optimal results according to the ranking index and those in which the weight of quality indicators determined by simple average formula [35]. Therefore, it is necessary to have studies to clarify the inconsistencies in solving multi-objective problems in EDM and propose methods to confirm the suitability of each MCDM method for specific problems. This will contribute to improving the accuracy of the optimal results. 
Table 1. Compliance analysis of optimal parameter selection method in the studies

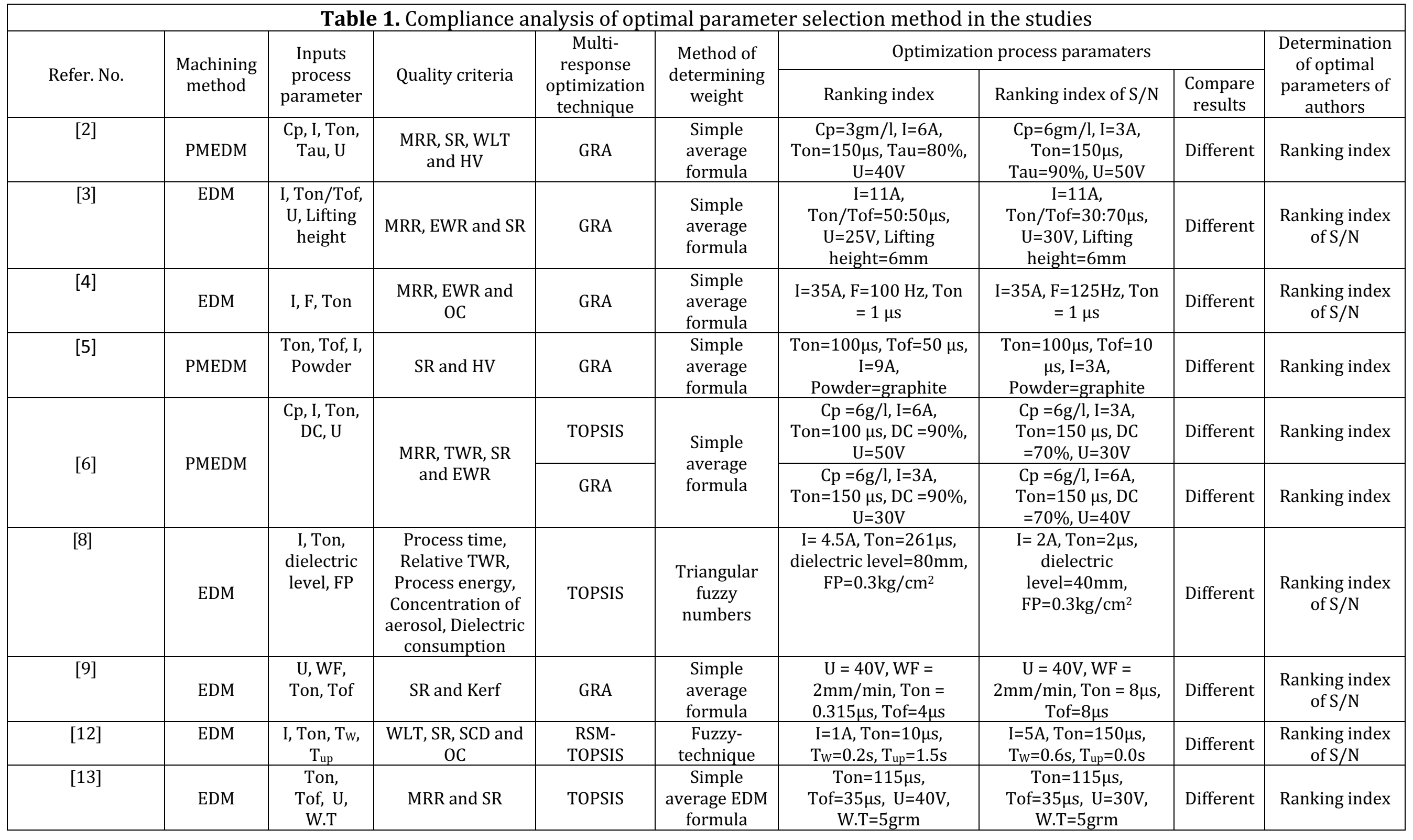




\begin{tabular}{|c|c|c|c|c|c|c|c|c|c|}
\hline [15] & EDM & $\begin{array}{l}\text { U, Ton, } \\
\text { Tof, WF }\end{array}$ & MRR, SR and Kerf & TOPSIS & Experience & U1, Ton3, Tof2, WF2. & U3, Ton3, Tof2, WF1. & Different & Ranking index \\
\hline [16] & EDM & $\begin{array}{l}\text { I, Ton, } \\
\text { Tof }\end{array}$ & $\begin{array}{c}\text { MRR, TWR, SR } \\
\text { and relative tool } \\
\text { wear ratio }\end{array}$ & GRA & $\begin{array}{l}\text { Fuzzy- } \\
\text { technique }\end{array}$ & $\begin{array}{c}\mathrm{I}=10 \mathrm{~A}, \text { Ton }=65 \mu \mathrm{s}, \\
\text { Tof }=48 \mu \mathrm{s}\end{array}$ & $\begin{array}{c}\mathrm{I}=10 \mathrm{~A}, \text { Ton }=65 \mu \mathrm{s}, \\
\text { Tof }=48 \mu \mathrm{s}\end{array}$ & Similary & $\begin{array}{c}\text { Ranking index } \\
\text { of } \mathrm{S} / \mathrm{N}\end{array}$ \\
\hline \multirow[b]{2}{*}{ [18] } & \multirow[b]{2}{*}{ EDM } & \multirow[t]{2}{*}{$\begin{array}{l}\text { Ton, } \\
\text { Tof, FP, } \\
\text { WF, W.T, } \\
\text { U, SF }\end{array}$} & \multirow[b]{2}{*}{ MRR and SR } & TOPSIS & \multirow[b]{2}{*}{ AHP } & $\begin{array}{c}\text { Ton }=120 \mu \mathrm{s}, \text { Tof }=45 \mu \mathrm{s}, \\
\mathrm{FP}=10 \mathrm{~kg} / \mathrm{cm}^{-2}, \\
\mathrm{WF}=3 \mathrm{~mm} / \mathrm{min}, \mathrm{W} . \mathrm{T}=7 \\
\text { grm, U=20V, SF }=1130 \\
\mathrm{~mm} / \mathrm{min}\end{array}$ & $\begin{array}{c}\text { Ton= } 130 \mu \mathrm{s}, \mathrm{Tof}=45 \mu \mathrm{s}, \\
\mathrm{FP}=10 \mathrm{~kg} / \mathrm{cm}^{-2}, \\
\mathrm{WF}=3 \mathrm{~mm} / \mathrm{min}, \mathrm{W} . \mathrm{T}=7 \\
\text { grm, } \mathrm{U}=20 \mathrm{~V}, \mathrm{SF}=1130 \\
\mathrm{~mm} / \mathrm{min}\end{array}$ & Different & $\begin{array}{c}\text { Ranking index } \\
\text { of } \mathrm{S} / \mathrm{N}\end{array}$ \\
\hline & & & & GRA & & $\begin{array}{c}\text { Ton }=130 \mu \mathrm{s}, \text { Tof }=55 \mu \mathrm{s}, \\
F P=5 \mathrm{~kg} / \mathrm{cm}^{-2} \\
W F=3 \mathrm{~mm} / \mathrm{min} \\
W . T=6.5 \mathrm{grm}, \mathrm{U}=20 \mathrm{~V} \\
\mathrm{SF}=1150 \mathrm{~mm} / \mathrm{min}\end{array}$ & $\begin{array}{c}\text { Ton }=130 \mu \mathrm{s}, \\
\text { Tof }=55 \mu \mathrm{s}, \\
\mathrm{FP}=10 \mathrm{~kg} / \mathrm{cm}^{-2}, \\
\mathrm{WF}=3 \mathrm{~mm} / \mathrm{min} \\
\mathrm{W} . \mathrm{T}=7 \mathrm{grm}, \mathrm{U}=20 \mathrm{~V} \\
\mathrm{SF}=1150 \mathrm{~mm} / \mathrm{min}\end{array}$ & Different & $\begin{array}{l}\text { Ranking index } \\
\text { of S/N }\end{array}$ \\
\hline [19] & EDM & $\begin{array}{l}\text { Ton, Tof, I, } \\
\text { U, WF, W.T }\end{array}$ & SR and Kerf & TOPSIS & $\begin{array}{l}\text { Standard } \\
\text { Deviation } \\
\text { (SDV) }\end{array}$ & $\begin{array}{c}\text { Ton }=108 \mu \mathrm{s}, \mathrm{Tof}=60 \mu \mathrm{s}, \\
\mathrm{I}=230 \mathrm{~A}, \mathrm{U}=50 \mathrm{~V} \\
\mathrm{WF}=5 \mathrm{~mm} / \mathrm{min}, \\
\mathrm{W} . \mathrm{T}=12 \mathrm{grm}\end{array}$ & $\begin{array}{c}\text { Ton }=108 \mu \mathrm{s}, \mathrm{Tof}=50 \mu \mathrm{s}, \\
\mathrm{I}=230 \mathrm{~A}, \mathrm{U}=30 \mathrm{~V}, \\
\mathrm{WF}=5 \mathrm{~mm} / \mathrm{min}, \\
\text { W.T }=8 \mathrm{grm}\end{array}$ & Different & Ranking index \\
\hline [20] & EDM & Ton, Tof, I & MRR, EWR and SR & TOPSIS & AHP & $\begin{array}{c}\text { Ton= } 1 \mu \mathrm{s}, \text { Tof }=6 \mu \mathrm{s}, \\
\mathrm{I}=3 \mathrm{~A}\end{array}$ & $\begin{array}{c}\text { Ton=1 } 1 \mu \mathrm{s}, \text { Tof }=1 \mu \mathrm{s}, \\
\mathrm{I}=3 \mathrm{~A}\end{array}$ & Different & $\begin{array}{c}\text { Ranking index } \\
\text { of S/N }\end{array}$ \\
\hline [21] & EDM & $\begin{array}{l}\text { Ton, Tof, } \\
\text { FP }\end{array}$ & MRR and TWR & GRA & $\begin{array}{c}\text { Simple } \\
\text { average } \\
\text { formula } \\
\end{array}$ & $\begin{array}{c}\text { Ton }=3 \mu \mathrm{s}, \text { Tof }=3 \mu \mathrm{s}, \\
\mathrm{FP}=7 \mathrm{~kg} / \mathrm{cm}^{2}\end{array}$ & $\begin{array}{c}\text { Ton }=9 \mu \mathrm{s}, \text { Tof }=3 \mu \mathrm{s}, \\
\mathrm{FP}=7 \mathrm{~kg} / \mathrm{cm}^{2}\end{array}$ & Different & $\begin{array}{l}\text { Ranking index } \\
\text { of S/N }\end{array}$ \\
\hline [23] & EDM & $\begin{array}{l}\text { I, Ton, } \\
\mathrm{Ta}, \mathrm{U}\end{array}$ & MRR and SR & TOPSIS & $\begin{array}{l}\text { Fuzzy- } \\
\text { technique }\end{array}$ & $\begin{array}{c}\mathrm{I}=6 \mathrm{~A}, \mathrm{Ton}=100 \mu \mathrm{s}, \\
\mathrm{Tau}=10, \mathrm{U}=50 \mathrm{~V}\end{array}$ & $\begin{array}{c}\mathrm{I}=2 \mathrm{~A}, \mathrm{Ton}=100 \mu \mathrm{s}, \\
\mathrm{Tau}=8, \mathrm{U}=45 \mathrm{~V}\end{array}$ & Different & $\begin{array}{c}\text { Ranking index } \\
\text { of } \mathrm{S} / \mathrm{N}\end{array}$ \\
\hline [25] & EDM & $\begin{array}{l}\text { I, Ton, } \\
\text { Ta }\end{array}$ & MRR, SR and ROC & $\begin{array}{l}\text { TOPSIS and } \\
\text { GRA }\end{array}$ & $\begin{array}{c}\text { Simple } \\
\text { average } \\
\text { formula } \\
\end{array}$ & $\begin{array}{c}\mathrm{I}=2 \mathrm{~A}, \mathrm{Ton}=150 \mu \mathrm{s}, \\
\text { Tau }=70\end{array}$ & $\begin{array}{c}\mathrm{I}=8 \mathrm{~A}, \mathrm{Ton}=50 \mu \mathrm{s} \\
\text { Tau }=90\end{array}$ & Different & $\begin{array}{l}\text { Ranking index } \\
\text { of S/N }\end{array}$ \\
\hline [31] & EDM & I, Ton, U & $\begin{array}{c}\text { MRR, SR and } \\
\text { Fractal dimension }\end{array}$ & TOPSIS & AHP & $\mathrm{I}=8 \mathrm{~A}, \mathrm{Ton}=5 \mu \mathrm{s}, \mathrm{U}=80 \mathrm{~V}$ & $\begin{array}{c}\mathrm{I}=8 \mathrm{~A}, \mathrm{Ton}=5 \mu \mathrm{s} \\
\mathrm{U}=100 \mathrm{~V}\end{array}$ & Different & $\begin{array}{c}\text { Ranking index } \\
\text { of S/N }\end{array}$ \\
\hline [32] & EDM & $\begin{array}{l}\text { WF, I, Ton, } \\
\quad \text { U }\end{array}$ & $\begin{array}{c}\text { TA, OC, Cent, } \\
\text { Cexit, MRR and } \\
\text { TWR, SR } \\
\end{array}$ & TOPSIS & $\begin{array}{l}\text { Simos } \\
\text { method }\end{array}$ & $\begin{array}{c}\mathrm{WF}=4 \mathrm{~mm} / \mathrm{s}, \mathrm{I}=10 \mathrm{~A}, \\
\mathrm{Ton}=15 \mu \mathrm{s}, \mathrm{U}=20 \mathrm{~V}\end{array}$ & $\begin{array}{c}\mathrm{WF}=4 \mathrm{~mm} / \mathrm{s}, \mathrm{I}=10 \mathrm{~A} \\
\mathrm{Ton}=10 \mu \mathrm{s}, \mathrm{U}=10 \mathrm{~V}\end{array}$ & Different & $\begin{array}{l}\text { Ranking index } \\
\text { of } \mathrm{S} / \mathrm{N}\end{array}$ \\
\hline [34] & EDM & $\begin{array}{l}\text { Wt, Ton, } \\
\text { Tof, WF, S }\end{array}$ & $\begin{array}{c}\text { CS, MRR, SR and } \\
\text { DD }\end{array}$ & DENG'S & AHP & $\begin{array}{c}\text { Zinc coated, Ton }=32 \mu \mathrm{s}, \\
\text { Tof }=6 \mu \mathrm{s}, \\
\mathrm{WF}=60 \mathrm{~mm} / \mathrm{min}, \\
\mathrm{S}=4 \mathrm{~mm} / \mathrm{min}\end{array}$ & $\begin{array}{c}\text { Zinc coated, } \\
\text { Ton=32 } \mu \mathrm{s}, \text { Tof }=6 \mu \mathrm{s}, \\
\mathrm{WF}=60 \mathrm{~mm} / \mathrm{min}, \\
\mathrm{S}=4 \mathrm{~mm} / \mathrm{min}\end{array}$ & Similary & Ranking index \\
\hline
\end{tabular}




\section{EXPERIMENTS AND METHODS}

Selection of process parameters in PMEDM: The number of process parameters in PMEDM is large, and a large amount of noise affects the research. Therefore, the choice of the process parameters and their level is tough to survey. There have been various approaches to choose the process parameters in previous studies. In this work, the process parameters and their levels were selected following the trends in recent publications and are oriented towards practical application of the research. The seven process parameters and their levels are provided in Table 2. The constant parameters are $\mathrm{GV}=150 \mathrm{~V}$; discharge gap of $200 \mu \mathrm{m}$ and machining time of $20 \mathrm{~min}$ for each experiment. The study aims to improve the productivity and machined surface quality by mixing titanium powder in to the dielectric. In accordance with previously published research, the size of titanium powder of $45 \mu \mathrm{m}$ was selected for our purposes.

Table 2. Input process parameter and their levels

\begin{tabular}{|c|c|c|c|c|c|c|}
\hline \multirow{2}{*}{$\begin{array}{l}\text { No } \\
\text { Exp. }\end{array}$} & \multirow{2}{*}{ Factors } & \multirow{2}{*}{ Symbols } & \multicolumn{3}{|c|}{ Level } & \multirow{2}{*}{ DOF } \\
\hline & & & Level 1 & Level 2 & Level 3 & \\
\hline 1 & Workpiece material & A & SKD61 & SKD11 & SKT4 & 2 \\
\hline 2 & Electrode material & B & $\mathrm{Cu}$ & $\mathrm{Cu}^{\mathrm{a}}$ & $\mathrm{Gr}$ & 1 \\
\hline 3 & Electrode polarity & $\mathrm{C}$ & $-\mathrm{a}$ & + & $-\mathrm{a}$ & 1 \\
\hline 4 & Ton $(\mu s)$ & $\mathrm{D}$ & 5 & 10 & 20 & 2 \\
\hline 5 & $\mathrm{I}(\mathrm{A})$ & $\mathrm{E}$ & 8 & 4 & 6 & 2 \\
\hline 6 & Tof $(\mu \mathrm{s})$ & $\mathrm{F}$ & 38 & 57 & 85 & 2 \\
\hline 7 & Powder concentrationTi(g/l) & G & 0 & 10 & 20 & 2 \\
\hline 8 & $\begin{array}{l}\text { Interaction of workpiece material } \\
\text { and electrode material }\end{array}$ & $\mathrm{A} \times \mathrm{B}$ & - & - & - & 2 \\
\hline 9 & $\begin{array}{l}\text { Interaction of workpiece material } \\
\text { and powder concentration }\end{array}$ & $A \times G$ & - & - & - & 4 \\
\hline 10 & $\begin{array}{l}\text { Interaction of electrode material and } \\
\text { powder concentration }\end{array}$ & $B \times G$ & - & - & - & 2 \\
\hline 11 & \multicolumn{5}{|l|}{ Total } & 20 \\
\hline
\end{tabular}

\subsection{Measurement of performance measures in PMEDM:}

The titanium powder was mixed into the dielectric fluid owing to its direct impact on the EDM processing mechanism. The PMEDM can lead to an increase in the size of the discharge gap-to enhance the number of sparks-and to a reduction in the dielectric strength of the dielectric fluid [30]. This phenomenon contributes to improving quality criteria such as MRR, TWR, SR, WLT, and the microcracking and topography of the machined surface [38]. During the process, a significant amount of electrode material and powder was melted and evaporated, and the dielectric solutions were cracked to produce carbon. Moreover, they penetrated the machined surface, making its physiology different from that of the base material. The improvement of quality criteria in PMEDM depends on the process parameters of the EDM machine and the characteristics of the powder which is mixed into the dielectric fluid. In this study, titanium powder $(\sim 45 \mu \mathrm{m})$ was selected for fine machining of PMEDM. Therefore, the quality criteria selected for study include the following:

Material removal rate (MRR): This rate is calculated by the amount of volume of workpiece material removed per minute. The MRR affects the productivity and time taken by the machining process. In our study, the volume of the excised workpiece was determined by the initial and final mass of workpiece using the following formula (Eq. 1). The mass of the workpiece was measured before and after processing with an electronic scale (Model; AJ-203, Shinko Denshi Co. Ltd, Japan), which can weigh up to a maximum of $200 \mathrm{~g}$ with an accuracy of $0.001 \mathrm{~g}$. 


$$
\operatorname{MRR}=\frac{\mathrm{w}_{\mathrm{b}}-\mathrm{W}_{\mathrm{a}}}{\rho_{\mathrm{w}} \cdot \mathrm{t}} \mathrm{mm}^{3} / \mathrm{min}
$$

where $W_{b}$ is the weight of workpiece before machining (gram), $W_{a}$ is the weight of workpiece after machining (gram), $t$ is machining time (min), $\rho_{w}$ is the density of the material (gram $/ \mathrm{mm}^{3}$ ).

Tool wear rate (TWR): TWR is the volume of electrode material that is eroded per minute. TWR is defined through a mathematical expression provided in Eq. 2. The corrosion-defective electrodes are measured in a manner similar to the erosionmeasurement method.

$$
\mathrm{TWR}=\frac{\mathrm{T}_{\mathrm{b}}-\mathrm{T}_{\mathrm{a}}}{\rho_{\mathrm{e}} \cdot \mathrm{t}}
$$

where $\mathrm{T}_{\mathrm{b}}$ is the tool-weight in grams before machining, and $\mathrm{T}_{\mathrm{a}}$ is the tool-weight after machining, while $\mathrm{t}$ is machining time $(\mathrm{min}), \rho_{\mathrm{e}}$ is the density of the tool material (gram $/ \mathrm{mm}^{3}$ ).

Surface roughness (SR): This criterion directly affects the smoothness of the surface after machining, and affects the choice of the next machining method after PMEDM. The SR was measured in PMEDM in terms of Ra, as defined in Eq. 3. Ra was measured using a surf test (Model: SJ-301, Mitutoyo Japan). The standard length was $5 \mathrm{~mm}$ for each measurement, with three replications on each sample.

$$
\mathrm{R}_{\mathrm{a}}=\frac{1}{\mathrm{~L}} \int_{0}^{L}|\mathrm{~h}(\mathrm{x})| \mathrm{dx}
$$

Where $\mathrm{L}$ is the sampling length $(\mathrm{mm}), \mathrm{h}$ is the profile curve, and $\mathrm{x}$ is the profile direction within $\mathrm{L}=0.8 \mathrm{~mm}$.

Micro-hardness of machined surface (HV): The key objective of using PMEDM with titanium powder in die steels machining is to improve the HV of the surface and the working ability of the moulds. The HV was measured using a micro-hardness tester (Model: Indenta Met-1106, Buehler USA) on the cross-sectional depth of the machined surface layer.

White layer thickness (WLT): In EDM, WLT will be discarded by refining methods [37]. However, mixing of titanium powder into the dielectric in EDM is aimed to improve the working ability of the white layer. Thus, WLT has a direct effect on the choice of residuals of the finishing. The durability of the mould surface was improved through PMEDM based titanium powder. The microstructure-layer surface was surveyed by photographic analysis of the cross-section of the machined surface layer taken using an optical microscope (Model: Axiovert-40MAT, Carl Zeiss Germany). The surface morphology was verified by a scanning electron microscope SEM (Model: JEOL-6490, Jeol Japan).

\subsection{Experimental layout design by dummy treatments for Taguchi method:}

The Taguchi method has been frequently used to optimize the process parameters of EDM and PMEDM. The Taguchi method was employed to design the experimental matrix. The quantitative and qualitative process parameters of the survey have been included. The price of the level of process parameters is arbitrary. The key motivation to use Taguchi method is that it offers control the noise factor, has provision of minimum experimental combinations, is user friendly and has minimum cost in terms of cost and materials.

The Taguchi method uses fixed matrix tables to design the experimental matrix [38]. The experimental matrix table was selected based on the number of process parameters, levels and the pairs of interaction between the parameters. In this study, seven process parameters and three pairs of interactions have been considered. They are list in Table 3. In these, five process parameters have three levels and two process parameters have two levels, so the degree of freedom is 20, (see Table 2). Taguchi's orthogonal matrix $L_{27}$, was selected to accommodate all the parameters listed in Table 3 . The positioning of process parameters into $\mathrm{L}_{27}$ matrix is illustrated accordingly in Fig $\mathbf{1 .}$ 


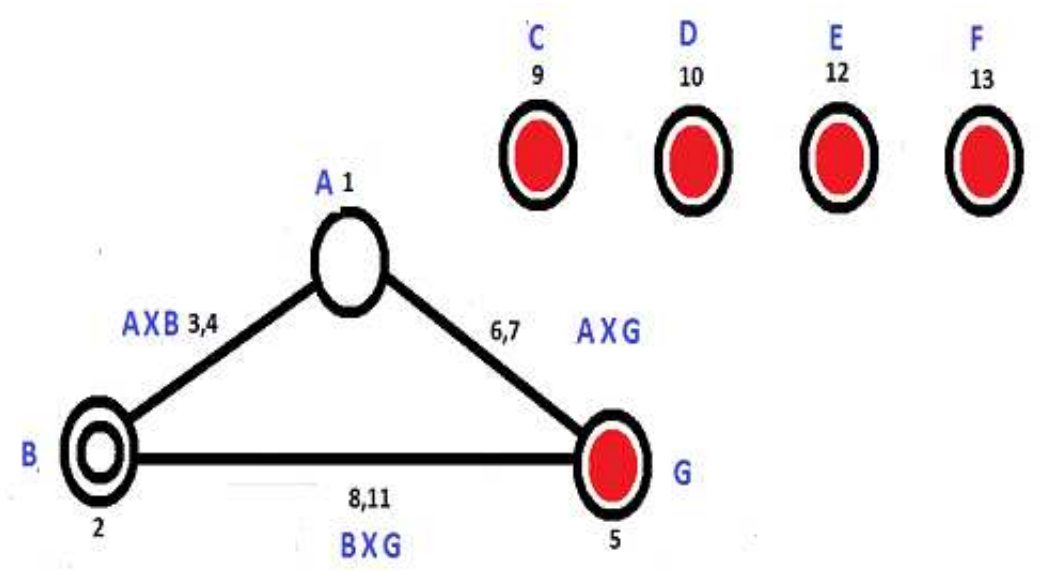

Fig. 1. Scheme assign objects for $L_{27}$ orthogonal array with dummy treat [38]

In Taguchi's orthogonal design, $\mathrm{S} / \mathrm{N}$ analysis was used to determine the optimal set of process parameters (Eq. 4). The S/N coefficient was calculated as follows [38]:

"Larger the better value":

$$
(S / N) L B=10 \log _{10}[M S D]
$$

In equation $4, M S D=\frac{1}{n}\left(\frac{1}{y_{1}^{2}}+\frac{1}{y_{2}^{2}}+\ldots \ldots \ldots \frac{1}{y_{n}^{2}}\right)$ is the average squared inverse of the measured values. Here, $y_{i} \mathrm{~s}$ and $\mathrm{n}$ represent the average squares of the experiment results and the number of experiments, respectively.

Table 3. The PMEDM performance measured results

\begin{tabular}{|c|c|c|c|c|c|c|c|c|c|c|c|c|}
\hline $\begin{array}{l}\text { Exp. } \\
\text { No }\end{array}$ & A & B & $\mathrm{C}$ & D & E & $\mathrm{F}$ & G & $\begin{array}{c}\text { MRR } \\
\left(\mathrm{mm}^{3} / \mathrm{min}\right)\end{array}$ & $\begin{array}{c}\text { TWR } \\
\left(\mathrm{mm}^{3} / \mathrm{min}\right)\end{array}$ & $\begin{array}{c}\text { SR } \\
(\mu \mathrm{m})\end{array}$ & $\begin{array}{c}\mathrm{HV} \\
(\mathrm{HV})\end{array}$ & $\begin{array}{l}\text { WLT } \\
(\mu \mathrm{m})\end{array}$ \\
\hline 1 & SKD61 & $\mathrm{Cu}$ & - & 5 & 8 & 38 & 0 & 10.487 & 1.95 & 3.35 & 506.7 & 10.56 \\
\hline 2 & SKD61 & $\mathrm{Cu}$ & + & 10 & 4 & 57 & 10 & 8.169 & 2.011 & 3.21 & 658.96 & 11.86 \\
\hline 3 & SKD61 & $\mathrm{Cu}$ & $-\mathrm{a}$ & 20 & 6 & 85 & 20 & 3.152 & 1.495 & 2.56 & 581.6 & 16.46 \\
\hline 4 & SKD61 & $\mathrm{Cu}^{\mathrm{a}}$ & + & 10 & 6 & 85 & 0 & 10.239 & 4.426 & 3.55 & 496.68 & 9.78 \\
\hline 5 & SKD61 & $\mathrm{Cu}^{\mathrm{a}}$ & $-\mathrm{a}$ & 20 & 8 & 38 & 10 & 14.304 & 4.364 & 3.61 & 828.92 & 14.78 \\
\hline 6 & SKD61 & $\mathrm{Cu}^{\mathrm{a}}$ & - & 5 & 4 & 57 & 20 & 0.089 & 0.054 & 1.45 & 629.84 & 7.631 \\
\hline 7 & SKD61 & $\mathrm{Gr}$ & $-\mathrm{a}$ & 20 & 4 & 57 & 0 & 37.466 & 11.499 & 4.78 & 544.58 & 7.91 \\
\hline 8 & SKD61 & $\mathrm{Gr}$ & - & 5 & 6 & 85 & 10 & 23.575 & 9.935 & 3.24 & 748.42 & 13.85 \\
\hline 9 & SKD61 & $\mathrm{Gr}$ & + & 10 & 8 & 38 & 20 & 38.843 & 19.626 & 4.35 & 626.18 & 15.33 \\
\hline 10 & SKD11 & $\mathrm{Cu}$ & + & 20 & 4 & 85 & 0 & 18.882 & 2.01 & 4.16 & 509.72 & 7.911 \\
\hline 11 & SKD11 & $\mathrm{Cu}$ & $-a$ & 5 & 6 & 38 & 10 & 3.857 & 1.179 & 2.05 & 679.54 & 13.43 \\
\hline 12 & SKD11 & $\mathrm{Cu}$ & - & 10 & 8 & 57 & 20 & 14.496 & 3.56 & 3.20 & 664.2 & 18.26 \\
\hline 13 & SKD11 & $\mathrm{Cu}^{\mathrm{a}}$ & $-\mathrm{a}$ & 5 & 8 & 57 & 0 & 10.608 & 2.25 & 3.35 & 546.02 & 11.26 \\
\hline 14 & SKD11 & $\mathrm{Cu}^{\mathrm{a}}$ & - & 10 & 4 & 85 & 10 & 0.320 & 0.132 & 2.04 & 679.2 & 10.25 \\
\hline 15 & SKD11 & $\mathrm{Cu}^{\mathrm{a}}$ & + & 20 & 6 & 38 & 20 & 23.577 & 1.495 & 4.57 & 655.18 & 14.38 \\
\hline 16 & SKD11 & Gr & - & 10 & 6 & 38 & 0 & 23.885 & 7.439 & 4.57 & 469.82 & 12.44 \\
\hline 17 & SKD11 & $\mathrm{Gr}$ & + & 20 & 8 & 57 & 10 & 59.669 & 14.073 & 4.45 & 907.64 & 8.56 \\
\hline 18 & SKD11 & $\mathrm{Gr}$ & $-\mathrm{a}$ & 5 & 4 & 85 & 20 & 17.159 & 5.491 & 2.74 & 683.52 & 7.631 \\
\hline 19 & SKT4 & $\mathrm{Cu}$ & $-\mathrm{a}$ & 10 & 6 & 57 & 0 & 1.252 & 0.587 & 2.55 & 530.72 & 14.26 \\
\hline 20 & SKT4 & $\mathrm{Cu}$ & - & 20 & 8 & 85 & 10 & 20.745 & 5.078 & 4.31 & 624.58 & 15.46 \\
\hline 21 & SKT4 & $\mathrm{Cu}$ & + & 5 & 4 & 38 & 20 & 4.374 & 2.902 & 2.46 & 631.68 & 7.915 \\
\hline 22 & SKT4 & $\mathrm{Cu}^{\mathrm{a}}$ & - & 20 & 4 & 38 & 0 & 0.198 & 0.277 & 2.26 & 468.04 & 8.574 \\
\hline 23 & SKT4 & $\mathrm{Cu}^{\mathrm{a}}$ & + & 5 & 6 & 57 & 10 & 6.782 & 4.715 & 2.89 & 544.38 & 12.45 \\
\hline 24 & SKT4 & $\mathrm{Cu}^{\mathrm{a}}$ & $-\mathrm{a}$ & 10 & 8 & 85 & 20 & 19.682 & 4.413 & 3.50 & 613.84 & 9.38 \\
\hline 25 & SKT4 & $\mathrm{Gr}$ & + & 5 & 8 & 85 & 0 & 10.649 & 4.537 & 3.23 & 445.44 & 11.62 \\
\hline 26 & SKT4 & $\mathrm{Gr}$ & $-\mathrm{a}$ & 10 & 4 & 38 & 10 & 25.970 & 9.041 & 3.24 & 681.22 & 14.68 \\
\hline 27 & SKT4 & $\mathrm{Gr}$ & - & 20 & 6 & 57 & 20 & 54.360 & 14.581 & 5.65 & 832.66 & 10.58 \\
\hline
\end{tabular}

$$
\text { a- Dummy treated }
$$


Step 1: Pairwise comparison is defined: We first consider all the factors in the subject matter and their purpose, and all the target elements and their results. This helps to determine whether the criteria have an impact, directly or indirectly, on the decisionmaking hierarchy of the study. Ratings for a pair of comparisons between two criteria are assigned using the Saaty scale [37] provided in Table 4. The number of pairwise comparisons is determined according to Table 5.

Table 4. Pairwise comparison scale of Saaty [37]

\begin{tabular}{|c|c|}
\hline $\begin{array}{c}\text { Intensity of } \\
\text { importance }\end{array}$ & Definition \\
\hline 1 & Equal importance \\
\hline 2 & Weak or slight \\
\hline 3 & Moderate importance \\
\hline 4 & Moderate plus \\
\hline 5 & Strong importance \\
\hline 6 & Strong plus \\
\hline 7 & Very strong or demonstrated importance \\
\hline 8 & Very, very strong \\
\hline 9 & Extreme importance \\
\hline
\end{tabular}

Step 2: Construct a comparison matrix: A comparison matrix is created after defining the objectives and criteria for building a hierarchical structure. The criteria and sub-criteria formed by comparing all criteria with each other and each sub-criteria with the higher subcriterion are shown in Table 5.

Table 5. Number of comparisons [37]

\begin{tabular}{|c|c|c|c|c|c|c|l|l|}
\hline $\begin{array}{c}\text { Number of } \\
\text { criteria }\end{array}$ & 1 & 2 & 3 & 4 & 5 & 6 & 7 & $\mathrm{n}$ \\
\hline $\begin{array}{c}\text { Number of } \\
\text { comparisons }\end{array}$ & 0 & 1 & 3 & 6 & 10 & 15 & 21 & $\frac{n(n-1)}{2}$ \\
\hline
\end{tabular}

Step 3: Calculate the consistency measure: Next, we build a normalized matrix to determine the value of the priority weight to evaluate the consistency of weight and the consistency ratio (CR). The CR ratio is calculated as follows:

Calculate the consistency index (CI): Multiply each column of the pairwise comparison matrix by the corresponding weight. Then divide of the sum of the row entries by the corresponding weight (Eq. 5). Compute the average of the values from step 3, denote it by $\lambda_{\max } \mathrm{CI}$ is calculated using Eq. 6 [37]:

$$
\mathrm{CI}=\frac{\lambda_{\max }-n}{\mathrm{n}-1}
$$

$\lambda$ max- This is the principal eigenvalue of comparison matrix

$\mathrm{n}$ - This is the number of criteria in the comparison matrix

Calculate the consistency ratio (CI/RCI where RCI is a random consistency index)

$$
\mathrm{CR}=\frac{\mathrm{CI}}{\mathrm{RCI}}
$$

Random Consistency index (RCI) as given in Table 6.

Table 6. Random Consistency Index (RCI) [37]

\begin{tabular}{|c|c|c|c|c|c|c|c|c|c|c|}
\hline $\mathrm{n}$ & 1 & 2 & 3 & 4 & 5 & 6 & 7 & 8 & 9 & 10 \\
\hline $\mathrm{RCI}$ & 0 & 0 & 0.58 & 0.9 & 1.12 & 1.24 & 1.32 & 1.41 & 1.45 & 1.49 \\
\hline
\end{tabular}

In AHP, the pairwise comparisons in a judgment matrix are considered to be adequately consistent if the corresponding consistency ratio (CR) is less than $10 \%$ [37]. 
Step 1: Sort the selected criteria in the form of a matrix: Determined by the Eq. 7:

$$
X=\left[\begin{array}{ccccc}
x_{11} & x_{12} & \cdot & x_{1 j} & x_{1 n} \\
x_{21} & x_{22} & \cdot & x_{2 j} & x_{2 n} \\
\cdot & \cdot & \cdot & \cdot & \cdot \\
x_{i 1} & x_{i 2} & \cdot & x_{i j} & x_{i n} \\
\cdot & \cdot & \cdot & \cdot & \cdot \\
x_{m 1} & x_{m 2} & \cdot & x_{m j} & x_{m n}
\end{array}\right]
$$

$\mathrm{x}_{11}, \mathrm{x}_{12}, \ldots, \mathrm{x}_{1 \mathrm{n}}-$ This is the criterion chosen in the optimization problem.

$\mathrm{x}_{11}, \mathrm{x}_{21}, \ldots, \mathrm{x}_{\mathrm{m} 1}-$ It is the value of indicator 1 at different levels.

$\mathrm{n}$ - Number of selected criteria.

$m$ - Number of the value of criteria.

Step 2: Standardize the matrix, and convert the criteria to the non-dimensional form in order to compare the values of various criteria (Eq 8). The normalization matrix is established through standardized values $\mathrm{x}_{\mathrm{ij}}{ }^{\prime}\left(0 \leq \mathrm{x}_{\mathrm{ij}}{ }^{\prime} \leq 1\right)$ :

$$
\begin{gathered}
x_{\mathrm{ij}}^{\prime}=\frac{x_{\mathrm{ij}}}{\sqrt{\sum_{i=1}^{n} x_{\mathrm{ij}}^{2}}} \\
\mathrm{X}^{\prime}=\left[\begin{array}{ccccc}
\mathrm{x}_{11}^{\prime} & \mathrm{x}_{12}^{\prime} & \cdot & \mathrm{x}_{1 \mathrm{j}}^{\prime} & \mathrm{x}_{\mathrm{ln}}^{\prime} \\
\mathrm{x}_{21}^{\prime} & \mathrm{x}_{22}^{\prime} & \cdot & \mathrm{x}_{2 \mathrm{j}}^{\prime} & \mathrm{x}_{2 \mathrm{n}}^{\prime} \\
\cdot & \cdot & \cdot & \cdot & \cdot \\
\mathrm{x}_{\mathrm{i} 1}^{\prime} & \mathrm{x}_{\mathrm{i} 2}^{\prime} & \cdot & \mathrm{x}_{\mathrm{ij}}^{\prime} & \mathrm{x}_{\mathrm{in}}^{\prime} \\
\cdot & \cdot & \cdot & \cdot & \cdot \\
\mathrm{x}_{\mathrm{m} 1}^{\prime} & \mathrm{x}_{\mathrm{m} 2}^{\prime} & \cdot & \mathrm{x}_{\mathrm{mj}}^{\prime} & \mathrm{x}_{\mathrm{mn}}^{\prime}
\end{array}\right]
\end{gathered}
$$

Step 3: Determine the weighted values of the criteria $\left(\mathrm{W}_{\mathrm{j}}\right)$ that are chosen. $\mathrm{W}_{\mathrm{j}}$ is determined by the AHP method.

Step 4: Assign weight of selected criteria in the standardized matrix. The normalized matrix with the weight of the criteria, best solution, and worst solution are defined as follows (Eq 9-11).

$$
\begin{aligned}
Y & =\mathrm{w}_{j} \cdot x_{\mathrm{ij}}^{\prime} \\
\mathrm{Y} & =\left[\begin{array}{ccccc}
y_{11} & \mathrm{y}_{12} & \cdot & \mathrm{y}_{1 \mathrm{j}} & \mathrm{y}_{1 \mathrm{n}} \\
\mathrm{y}_{21} & \mathrm{y}_{22} & \cdot & \mathrm{y}_{2 \mathrm{j}} & \mathrm{y}_{2 \mathrm{n}} \\
\cdot & \cdot & \cdot & \cdot & \cdot \\
\mathrm{y}_{\mathrm{i} 1} & \mathrm{y}_{\mathrm{i} 2} & \cdot & \mathrm{y}_{\mathrm{ij}} & \mathrm{y}_{\mathrm{in}} \\
\cdot & \cdot & \cdot & \cdot & \cdot \\
\mathrm{y}_{\mathrm{m} 1} & \mathrm{y}_{\mathrm{m} 2} & \cdot & \mathrm{y}_{\mathrm{mj}} & \mathrm{y}_{\mathrm{mn}}
\end{array}\right]
\end{aligned}
$$

$\mathrm{W}_{\mathrm{j}}$ - Weight of quality criteria.

Y - Standardized matrix of weighted criteria

Step 5: Identify the best solution and the worst solution alternatives depicted in Fig. 2 


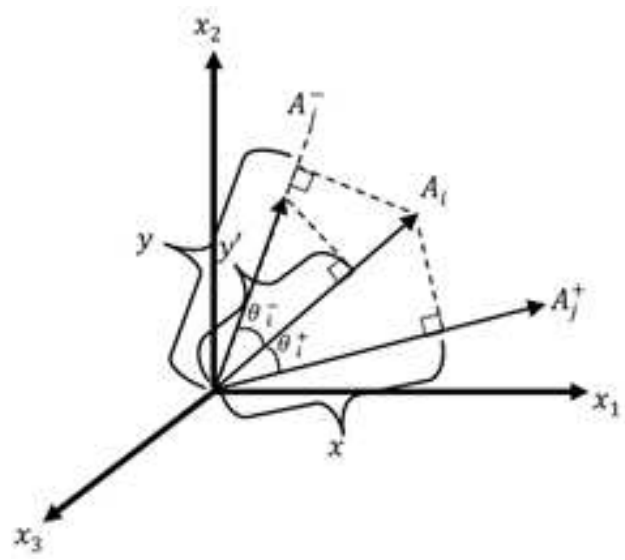

Fig. 2. The degree of conflict between alternatives and $A_{j}{ }^{+}\left(A_{j}{ }^{-}\right)[28]$.

The optimum solution:

$$
\begin{aligned}
& A^{+}=\left\{\left(\max _{i} \mathrm{y}_{\mathrm{ij}} \mid \in J\right),\left(\min _{i} y_{\mathrm{ij}}\left|j \in J^{\prime}\right| i=1,2, \ldots, m\right)\right\} \\
& A^{+}=\left\{y_{1}^{+}, y_{2}^{+}, \ldots, y_{j}^{+}, \ldots, y_{n}^{+}\right\}
\end{aligned}
$$

The worst solution:

$$
\begin{aligned}
& A^{-}=\left\{\left(\min _{i} \mathrm{y}_{\mathrm{ij}} \mid \in J\right),\left(\max _{i} y_{\mathrm{ij}}\left|j \in J^{\prime}\right| i=1,2, \ldots, m\right)\right\} \\
& A^{-}=\left\{y_{1}^{-}, y_{2}^{-}, \ldots, y_{j}^{-}, \ldots, y_{n}^{-}\right\}
\end{aligned}
$$

(The worst criteria)

where

- J combined with good criteria

- J' combined with bad criteria.

$-y_{j}^{+}$- is the best value of $\mathrm{x}_{\mathrm{j}}$.

- $y_{j}^{-}$- is the worst value of $\mathrm{x}_{\mathbf{j}}$.

Step 6: Calculate the degree of conflict between each option. The degree of conflict between each alternative and positive ideal solution and the negative ideal solution can be calculated as follow:

$$
\begin{aligned}
& A_{j}, A^{ \pm}=\left|A_{i}\right|\left|A^{ \pm}\right| \cos \theta_{i}^{ \pm} \\
& A_{j}, A^{ \pm}=\sum_{i=1}^{n} y_{\mathrm{ij}}^{\prime} y_{i}^{ \pm} \\
& \left|A_{j}\right|=\left(\sum_{i=1}^{n} y_{\mathrm{ij}}^{2}\right)^{0.5} \\
& A^{ \pm}=\left(\sum_{i=1}^{n} y_{\mathrm{ij}}^{ \pm 2}\right)^{0.5}
\end{aligned}
$$

The conflict between the alternative and positive ideal solution is defined in Eq. 12:

$$
\operatorname{Cos} \theta_{\mathrm{i}}^{+}=\frac{\sum_{\mathrm{i}=1}^{\mathrm{n}} \mathrm{y}_{\mathrm{ij}} \cdot \mathrm{y}_{i}^{+}}{\sqrt{\left[\sum_{\mathrm{i}=1}^{\mathrm{n}} \mathrm{y}_{\mathrm{ij}}^{2}\right]} \sqrt{\left[\sum_{\mathrm{i}=1}^{\mathrm{n}} \mathrm{y}_{\mathrm{ij}}^{+2}\right]}}
$$

The conflict between the alternative and negative ideal solution is obtained in Eq. 13: 


$$
\cos \theta_{i}^{-}=\frac{\sum_{i=1}^{n} y_{i j} \cdot y_{j}^{-}}{\sqrt{\left[\sum_{i=1}^{n} y_{i j}^{2}\right]} \sqrt{\left[\sum_{i=1}^{n} y_{i j}^{-2}\right]}}
$$

Where $\theta$ value lies between $0^{0}$ and $90^{\circ}$.

Step 7: The degree of similarity and conflict between the alternatives and the ideal positive and negative solutions are calculated as follows (Eqs. 14 and 15):

The degree of conflict:

$$
\left|\mathrm{DC}_{\mathrm{i}}\right|=\cos \theta_{i}^{-+} \times\left|A_{i}\right|
$$

Degree of similarity:

$$
\begin{aligned}
& D S_{i}^{-}=\frac{\left|D C_{i}\right|}{\left|A_{i}^{-}\right|}=\frac{\cos \theta_{i}^{-} \times\left|A_{i}\right|}{\left|A_{i}^{-}\right|} \\
& D S_{i}^{+}=\frac{\left|D C_{i}\right|}{\left|A_{i}^{+}\right|}=\frac{\cos \theta_{i}^{+} \times\left|A_{i}\right|}{\left|A_{i}^{+}\right|}
\end{aligned}
$$

Step 8: The overall performance index for each alternative is calculated as (Eq. 16):

$$
P_{i}=\frac{D S_{i}^{+}}{D S_{i}^{+}+D S_{i}^{-}}
$$

Step 9: Ranking according to Deng's similarity-based method.

\section{RESULTS AND DISCUSSION}

\subsection{Computation of Taguchi - AHP - Deng's:}

In this study, Taguchi-AHP-Deng's method was used to simultaneously optimize the five output criteria in PMEDM: MRR, TWR, SR, HV, and WLT. The steps followed to achieve this are as follows:

Step 1: Sort the selected criteria in a matrix form.

Step 2: Standardize the matrix in Table 7.

$$
\mathrm{X}=\left[\begin{array}{ccccc}
\mathrm{MRR}_{1} & \mathrm{TWR}_{1} & \mathrm{SR}_{1} & \mathrm{HV}_{1} & \mathrm{WLT}_{1} \\
\mathrm{MRR}_{2} & \mathrm{TWR}_{2} & \mathrm{SR}_{2} & \mathrm{HV}_{2} & \mathrm{WLT}_{2} \\
\cdot & \cdot & \cdot & \cdot & \cdot \\
\cdot & \cdot & \cdot & \cdot & \cdot \\
\cdot & \cdot & \cdot & \cdot & \cdot \\
\mathrm{MRR}_{27} & \mathrm{TWR}_{27} & \mathrm{SR}_{27} & \mathrm{HV}_{27} & \mathrm{WLT}_{27}
\end{array}\right]
$$

Table 7. Transformation matrix of quality criteria

\begin{tabular}{|c|c|c|c|c|c|c|c|c|c|c|c|c|}
\hline $\begin{array}{c}\text { Exp. } \\
\text { No }\end{array}$ & $\mathrm{A}$ & \multirow{2}{*}{$\mathrm{B}$} & $\mathrm{C}$ & $\mathrm{D}$ & $\mathrm{E}$ & \multirow{2}{*}{$\mathrm{F}$} & $\mathrm{G}$ & \multicolumn{6}{|c|}{$\mathrm{X}^{\prime}$} \\
\hline & & & & & & & & MRR & TWR & SR & HV & WLT \\
\hline 1 & SKD61 & $\mathrm{Cu}$ & - & 5 & 8 & 38 & 0 & 0.088 & 0.053 & 0.183 & 0.154 & 0.168 \\
\hline 2 & SKD61 & $\mathrm{Cu}$ & + & 10 & 4 & 57 & 10 & 0.068 & 0.054 & 0.176 & 0.201 & 0.188 \\
\hline 3 & SKD61 & $\mathrm{Cu}$ & $-\mathrm{a}$ & 20 & 6 & 85 & 20 & 0.026 & 0.040 & 0.140 & 0.177 & 0.261 \\
\hline 4 & SKD61 & $\mathrm{Cu}^{\mathrm{a}}$ & + & 10 & 6 & 85 & 0 & 0.086 & 0.120 & 0.194 & 0.151 & 0.155 \\
\hline 5 & SKD61 & $\mathrm{Cu}^{\mathrm{a}}$ & $-\mathrm{a}$ & 20 & 8 & 38 & 10 & 0.120 & 0.118 & 0.198 & 0.252 & 0.235 \\
\hline 6 & SKD61 & $\mathrm{Cu}^{\mathrm{a}}$ & - & 5 & 4 & 57 & 20 & 0.001 & 0.001 & 0.079 & 0.192 & 0.121 \\
\hline 7 & SKD61 & $\mathrm{Gr}$ & $-\mathrm{a}$ & 20 & 4 & 57 & 0 & 0.314 & 0.311 & 0.262 & 0.166 & 0.126 \\
\hline 8 & SKD61 & $\mathrm{Gr}$ & - & 5 & 6 & 85 & 10 & 0.197 & 0.269 & 0.177 & 0.228 & 0.220 \\
\hline 9 & SKD61 & $\mathrm{Gr}$ & + & 10 & 8 & 38 & 20 & 0.325 & 0.531 & 0.238 & 0.191 & 0.243 \\
\hline 10 & SKD11 & $\mathrm{Cu}$ & + & 20 & 4 & 85 & 0 & 0.158 & 0.054 & 0.228 & 0.155 & 0.126 \\
\hline
\end{tabular}




\begin{tabular}{|c|c|c|c|c|c|c|c|c|c|c|c|c|}
\hline 11 & SKD11 & $\mathrm{Cu}$ & $-\mathrm{a}$ & 5 & 6 & 38 & 10 & 0.032 & 0.032 & 0.112 & 0.207 & 0.213 \\
\hline 12 & SKD11 & $\mathrm{Cu}$ & - & 10 & 8 & 57 & 20 & 0.121 & 0.096 & 0.175 & 0.202 & 0.290 \\
\hline 13 & SKD11 & $\mathrm{Cu}^{\mathrm{a}}$ & $-\mathrm{a}$ & 5 & 8 & 57 & 0 & 0.089 & 0.061 & 0.183 & 0.166 & 0.179 \\
\hline 14 & SKD11 & $\mathrm{Cu}^{\mathrm{a}}$ & - & 10 & 4 & 85 & 10 & 0.003 & 0.004 & 0.112 & 0.207 & 0.163 \\
\hline 15 & SKD11 & $\mathrm{Cu}^{\mathrm{a}}$ & + & 20 & 6 & 38 & 20 & 0.197 & 0.040 & 0.250 & 0.199 & 0.228 \\
\hline 16 & SKD11 & $\mathrm{Gr}$ & - & 10 & 6 & 38 & 0 & 0.200 & 0.201 & 0.250 & 0.143 & 0.197 \\
\hline 17 & SKD11 & $\mathrm{Gr}$ & + & 20 & 8 & 57 & 10 & 0.500 & 0.381 & 0.243 & 0.276 & 0.136 \\
\hline 18 & SKD11 & $\mathrm{Gr}$ & $-\mathrm{a}$ & 5 & 4 & 85 & 20 & 0.144 & 0.149 & 0.150 & 0.208 & 0.121 \\
\hline 19 & SKT4 & $\mathrm{Cu}$ & $-\mathrm{a}$ & 10 & 6 & 57 & 0 & 0.010 & 0.016 & 0.140 & 0.162 & 0.226 \\
\hline 20 & SKT4 & $\mathrm{Cu}$ & - & 20 & 8 & 85 & 10 & 0.174 & 0.137 & 0.236 & 0.190 & 0.245 \\
\hline 21 & SKT4 & $\mathrm{Cu}$ & + & 5 & 4 & 38 & 20 & 0.037 & 0.079 & 0.135 & 0.192 & 0.126 \\
\hline 22 & SKT4 & $\mathrm{Cu}^{\mathrm{a}}$ & - & 20 & 4 & 38 & 0 & 0.002 & 0.007 & 0.124 & 0.142 & 0.136 \\
\hline 23 & SKT4 & $\mathrm{Cu}^{\mathrm{a}}$ & + & 5 & 6 & 57 & 10 & 0.057 & 0.128 & 0.158 & 0.166 & 0.198 \\
\hline 24 & SKT4 & $\mathrm{Cu}^{\mathrm{a}}$ & $-\mathrm{a}$ & 10 & 8 & 85 & 20 & 0.165 & 0.119 & 0.192 & 0.187 & 0.149 \\
\hline 25 & SKT4 & $\mathrm{Gr}+$ & 5 & 8 & 85 & 0 & 0.089 & 0.123 & 0.177 & 0.136 & 0.184 \\
\hline 26 & SKT4 & $\mathrm{Gr}^{-\mathrm{a}}$ & 10 & 4 & 38 & 10 & 0.217 & 0.245 & 0.177 & 0.207 & 0.233 \\
\hline 27 & SKT4 & $\mathrm{Gr}^{2}-$ & 20 & 6 & 57 & 20 & 0.088 & 0.053 & 0.183 & 0.154 & 0.168 \\
\hline
\end{tabular}
a-Dummy treated

Step 3: Determine the weight value of the criteria (Wj) selected. $\mathrm{Wj}$ is determined by the AHP method. The weight value are as follows: Identify comparison pairs and normalization. These are shown in Table 8 and Table 9 respectively. The consistency measure is shown in Table 9; $\mathrm{CI}$ is determined by (5): with $\lambda \max =5.12, \mathrm{CI}=0.03$; Calculate the consistency ratio according to $(6)$ : $\mathrm{RCI}=1.12, \mathrm{CR}=0.0272<0.1$. Weighted values of quality criteria are shown in Table 9:

Table 8. Pairwise comparison matrix of the main criteria concerning the Goal

\begin{tabular}{|c|c|c|c|c|c|}
\hline Factor & MRR & SR & TWR & HV & WTL \\
\hline MRR & 1 & $1 / 2$ & 3 & $1 / 3$ & $1 / 2$ \\
\hline SR & 3 & 1 & 8 & 1 & 2 \\
\hline TWR & $1 / 3$ & $1 / 8$ & 1 & $1 / 7$ & $1 / 5$ \\
\hline HV & 3 & 1 & 7 & 1 & 2 \\
\hline WTL & 2 & $1 / 2$ & 5 & $1 / 2$ & 1 \\
\hline Total & $28 / 3$ & $25 / 8$ & 24 & $125 / 42$ & $57 / 10$ \\
\hline
\end{tabular}

Table 9. Normalize the matrix and the weight of quality criteria

\begin{tabular}{|c|c|c|c|c|c|c|c|c|}
\hline Factor & MRR & SR & TWR & HV & WTL & Total & $\begin{array}{c}\text { Consistency } \\
\text { Measure }\end{array}$ & Weighted \\
\hline MRR & 0.107 & 0.161 & 0.120 & 0.112 & 0.088 & 0.588 & 5.126 & 0,119 \\
\hline SR & 0.321 & 0.321 & 0.360 & 0.336 & 0.351 & 1.690 & 5.119 & 0,378 \\
\hline TWR & 0.036 & 0.036 & 0.040 & 0.048 & 0.035 & 0.195 & 5.099 & 0,039 \\
\hline HV & 0.321 & 0.321 & 0.280 & 0.336 & 0.351 & 1.610 & 5.132 & 0,281 \\
\hline WTL & 0.214 & 0.161 & 0.200 & 0.168 & 0.175 & 0.918 & 5.135 & 0,183 \\
\hline
\end{tabular}

Step 4: Assign the weight of the selected quality criteria to the normalized matrix.(See Table 10.)

Table 10. Normalization matrix of quality criteria with weights

\begin{tabular}{|c|c|c|c|c|c|c|c|c|c|c|c|c|}
\hline \multirow{2}{*}{$\begin{array}{c}\text { Exp. } \\
\text { No }\end{array}$} & \multirow{2}{*}{ A } & \multirow{2}{*}{ B } & \multirow{2}{*}{ C } & \multirow{2}{*}{ D } & \multirow{2}{*}{ E } & \multirow{2}{*}{$\mathrm{F}$} & \multirow{2}{*}{ G } & \multicolumn{5}{|c|}{$\mathrm{y}^{\prime}$} \\
\hline & & & & & & & & MRR & TWR & SR & $\mathrm{HV}$ & WLT \\
\hline 1 & SKD61 & $\mathrm{Cu}$ & - & 5 & 8 & 38 & 0 & 0.010 & 0.002 & 0.062 & 0.050 & 0.031 \\
\hline 2 & SKD61 & $\mathrm{Cu}$ & + & 10 & 4 & 57 & 10 & 0.020 & 0.002 & 0.077 & 0.024 & 0.035 \\
\hline 3 & SKD61 & $\mathrm{Cu}$ & $-\mathrm{a}$ & 20 & 6 & 85 & 20 & 0.008 & 0.002 & 0.061 & 0.021 & 0.048 \\
\hline
\end{tabular}




\begin{tabular}{|c|c|c|c|c|c|c|c|c|c|c|c|c|}
\hline 4 & SKD61 & $\mathrm{Cu}^{\mathrm{a}}$ & + & 10 & 6 & 85 & 0 & 0.025 & 0.005 & 0.085 & 0.018 & 0.029 \\
\hline 5 & SKD61 & $\mathrm{Cu}^{\mathrm{a}}$ & $-\mathrm{a}$ & 20 & 8 & 38 & 10 & 0.035 & 0.005 & 0.086 & 0.030 & 0.043 \\
\hline 6 & SKD61 & $\mathrm{Cu}^{\mathrm{a}}$ & - & 5 & 4 & 57 & 20 & 0.000 & 0.000 & 0.035 & 0.023 & 0.022 \\
\hline 7 & SKD61 & $\mathrm{Gr}$ & $-\mathrm{a}$ & 20 & 4 & 57 & 0 & 0.090 & 0.013 & 0.114 & 0.019 & 0.023 \\
\hline 8 & SKD61 & $\mathrm{Gr}$ & - & 5 & 6 & 85 & 10 & 0.057 & 0.011 & 0.077 & 0.027 & 0.040 \\
\hline 9 & SKD61 & $\mathrm{Gr}$ & + & 10 & 8 & 38 & 20 & 0.094 & 0.022 & 0.104 & 0.022 & 0.045 \\
\hline 10 & SKD11 & $\mathrm{Cu}$ & + & 20 & 4 & 85 & 0 & 0.046 & 0.002 & 0.099 & 0.018 & 0.023 \\
\hline 11 & SKD11 & $\mathrm{Cu}$ & $-\mathrm{a}$ & 5 & 6 & 38 & 10 & 0.009 & 0.001 & 0.049 & 0.024 & 0.039 \\
\hline 12 & SKD11 & $\mathrm{Cu}$ & - & 10 & 8 & 57 & 20 & 0.035 & 0.004 & 0.076 & 0.024 & 0.053 \\
\hline 13 & SKD11 & $\mathrm{Cu}^{\mathrm{a}}$ & $-\mathrm{a}$ & 5 & 8 & 57 & 0 & 0.026 & 0.003 & 0.080 & 0.020 & 0.033 \\
\hline 14 & SKD11 & $\mathrm{Cu}^{\mathrm{a}}$ & - & 10 & 4 & 85 & 10 & 0.001 & 0.000 & 0.049 & 0.024 & 0.030 \\
\hline 15 & SKD11 & $\mathrm{Cu}^{\mathrm{a}}$ & + & 20 & 6 & 38 & 20 & 0.057 & 0.002 & 0.109 & 0.023 & 0.042 \\
\hline 16 & SKD11 & $\mathrm{Gr}$ & - & 10 & 6 & 38 & 0 & 0.058 & 0.008 & 0.109 & 0.017 & 0.036 \\
\hline 17 & SKD11 & $\mathrm{Gr}$ & + & 20 & 8 & 57 & 10 & 0.144 & 0.016 & 0.106 & 0.032 & 0.025 \\
\hline 18 & SKD11 & $\mathrm{Gr}$ & $-\mathrm{a}$ & 5 & 4 & 85 & 20 & 0.041 & 0.006 & 0.065 & 0.024 & 0.022 \\
\hline 19 & SKT4 & $\mathrm{Cu}^{-a}$ & 10 & 6 & 57 & 0 & 0.003 & 0.001 & 0.061 & 0.019 & 0.042 \\
\hline 20 & SKT4 & $\mathrm{Cu}^{-}$ & 20 & 8 & 85 & 10 & 0.050 & 0.006 & 0.103 & 0.022 & 0.045 \\
\hline 21 & SKT4 & $\mathrm{Cu}^{+}+$ & 5 & 4 & 38 & 20 & 0.011 & 0.003 & 0.059 & 0.023 & 0.023 \\
\hline 22 & SKT4 & $\mathrm{Cu}^{\mathrm{a}}$ & - & 20 & 4 & 38 & 0 & 0.000 & 0.000 & 0.054 & 0.017 & 0.025 \\
\hline 23 & SKT4 & $\mathrm{Cu}^{\mathrm{a}}$ & + & 5 & 6 & 57 & 10 & 0.016 & 0.005 & 0.069 & 0.019 & 0.036 \\
\hline 24 & SKT4 & $\mathrm{Cu}^{\mathrm{a}}$ & $-\mathrm{a}$ & 10 & 8 & 85 & 20 & 0.048 & 0.005 & 0.084 & 0.022 & 0.027 \\
\hline 25 & SKT4 & $\mathrm{Gr}^{+}$ & 5 & 8 & 85 & 0 & 0.026 & 0.005 & 0.077 & 0.016 & 0.034 \\
\hline 26 & SKT4 & $\mathrm{Gr}^{-a}$ & 10 & 4 & 38 & 10 & 0.063 & 0.010 & 0.077 & 0.024 & 0.043 \\
\hline 27 & SKT4 & $\mathrm{Gr}^{2}-$ & 20 & 6 & 57 & 20 & 0.131 & 0.016 & 0.135 & 0.030 & 0.031 \\
\hline
\end{tabular}

$a_{-}$Dummy treated; $W_{M R R}=0.119, W_{T W R}=0.039, W_{S R}=0.378, W_{H V}=0.281, W_{W L T}=0.183$.

Step 5: Identify the best solution and the worst solution: Positive ideal solution and the negative ideal solution, Table 11.

Table 11. Positive ideal solution and negative ideal solution

\begin{tabular}{|c|c|c|c|c|c|}
\hline \multirow{2}{*}{ Solution } & \multicolumn{5}{|c|}{ Quality criterion } \\
\cline { 2 - 6 } & MRR & TWR & SR & HV & WLT \\
\hline $\mathrm{A}^{+}$ & 0.144 & 0.000 & 0.035 & 0.050 & 0.022 \\
\hline $\mathrm{A}^{-}$ & 0.000 & 0.022 & 0.114 & 0.016 & 0.053 \\
\hline
\end{tabular}

Step 6-8: Calculate the degree of conflict between each option, Table 12.

Step 9: Ranking index by Deng's method: The results show that the $17^{\text {th }}$ experiment received the largest $\mathrm{Pi}$. Therefore, the $17^{\text {th }}$ experiment will give optimum efficiency is best, optimal process parameters (Table 12) are SKD11, Gr (+), Ton $=20 \mu \mathrm{s}, \mathrm{I}=8 \mathrm{~A}$, Tof $=57 \mu \mathrm{s}$, $10 \mathrm{~g} / \mathrm{l}$. Quality characteristics at optimal process parameters includes MRR $=59.669$ $\mathrm{mm}^{3} / \mathrm{min}, \mathrm{TWR}=14.073 \mathrm{~mm}^{3} / \mathrm{min}, \mathrm{SR}=4.45 \mu \mathrm{m}, \mathrm{HV}=907.64 \mathrm{HV}, \mathrm{WLT}=8.56 \mu \mathrm{m}$.

Table 12. Calculating the conflict index and ranking the alternatives

\begin{tabular}{|c|c|c|c|c|c|c|c|c|c|c|}
\hline $\begin{array}{c}\text { Exp. } \\
\text { No }\end{array}$ & $\mathrm{Ai}$ & $\operatorname{Cos} \theta^{+}$ & $\operatorname{Cos} \theta^{-}$ & $\mathrm{DC}^{+}$ & $\mathrm{DC}^{-}$ & $\mathrm{DS}^{+}$ & $\mathrm{DS}^{-}$ & $\mathrm{Pi}$ & Rank & $\begin{array}{c}\mathrm{S} / \mathrm{N} \\
\text { of Pi }\end{array}$ \\
\hline 1 & 0.0068 & 0.506 & 0.863 & 0.043 & 0.074 & 0.278 & 0.575 & 0.326 & 17 & -4.714 \\
\hline 2 & 0.0074 & 0.531 & 0.955 & 0.048 & 0.086 & 0.305 & 0.664 & 0.315 & 19 & -2.281 \\
\hline 3 & 0.0053 & 0.421 & 0.951 & 0.034 & 0.077 & 0.218 & 0.596 & 0.267 & 23 & -2.984 \\
\hline 4 & 0.0080 & 0.542 & 0.951 & 0.051 & 0.090 & 0.328 & 0.698 & 0.320 & 18 & -5.211 \\
\hline 5 & 0.0104 & 0.623 & 0.925 & 0.067 & 0.099 & 0.426 & 0.766 & 0.357 & 14 & -1.281 \\
\hline 6 & 0.0028 & 0.388 & 0.909 & 0.018 & 0.043 & 0.116 & 0.331 & 0.260 & 24 & -2.044 \\
\hline 7 & 0.0185 & 0.791 & 0.773 & 0.118 & 0.115 & 0.756 & 0.896 & 0.458 & 4 & -5.749 \\
\hline 8 & 0.0131 & 0.775 & 0.837 & 0.084 & 0.091 & 0.537 & 0.703 & 0.433 & 6 & -1.515 \\
\hline 9 & 0.0192 & 0.818 & 0.780 & 0.123 & 0.117 & 0.787 & 0.909 & 0.464 & 3 & -3.387 \\
\hline 10 & 0.0114 & 0.646 & 0.886 & 0.073 & 0.100 & 0.468 & 0.778 & 0.376 & 11 & -6.096 \\
\hline
\end{tabular}




\begin{tabular}{|l|l|l|l|l|l|l|l|l|l|l|}
\hline 11 & 0.0051 & 0.482 & 0.925 & 0.033 & 0.063 & 0.210 & 0.487 & 0.301 & 21 & -1.822 \\
\hline 12 & 0.0101 & 0.628 & 0.912 & 0.064 & 0.093 & 0.412 & 0.724 & 0.362 & 13 & -2.345 \\
\hline 13 & 0.0082 & 0.566 & 0.946 & 0.052 & 0.087 & 0.334 & 0.678 & 0.330 & 15 & -4.115 \\
\hline 14 & 0.0037 & 0.378 & 0.942 & 0.023 & 0.059 & 0.150 & 0.454 & 0.249 & 25 & -1.860 \\
\hline 15 & 0.0141 & 0.682 & 0.888 & 0.090 & 0.117 & 0.577 & 0.910 & 0.388 & 9 & -3.236 \\
\hline 16 & 0.0137 & 0.676 & 0.887 & 0.088 & 0.115 & 0.562 & 0.894 & 0.386 & 10 & -8.224 \\
\hline 17 & 0.0266 & 0.923 & 0.605 & 0.170 & 0.111 & 1.089 & 0.865 & 0.558 & $\mathbf{1}$ & -1.108 \\
\hline 18 & 0.0099 & 0.754 & 0.845 & 0.064 & 0.071 & 0.407 & 0.553 & 0.424 & 7 & -1.904 \\
\hline 19 & 0.0044 & 0.373 & 0.966 & 0.028 & 0.074 & 0.182 & 0.571 & 0.242 & 26 & -3.544 \\
\hline 20 & 0.0129 & 0.661 & 0.908 & 0.083 & 0.114 & 0.530 & 0.882 & 0.375 & 12 & -3.599 \\
\hline 21 & 0.0052 & 0.491 & 0.956 & 0.033 & 0.065 & 0.213 & 0.504 & 0.298 & 22 & -2.395 \\
\hline 22 & 0.0033 & 0.344 & 0.975 & 0.021 & 0.060 & 0.136 & 0.468 & 0.226 & 27 & -3.829 \\
\hline 23 & 0.0065 & 0.508 & 0.967 & 0.042 & 0.079 & 0.267 & 0.617 & 0.302 & 20 & -3.663 \\
\hline 24 & 0.0114 & 0.714 & 0.868 & 0.073 & 0.089 & 0.469 & 0.690 & 0.404 & 8 & -3.118 \\
\hline 25 & 0.0079 & 0.565 & 0.950 & 0.051 & 0.085 & 0.324 & 0.661 & 0.329 & 16 & -5.179 \\
\hline 26 & 0.0139 & 0.796 & 0.817 & 0.089 & 0.091 & 0.568 & 0.707 & 0.446 & 5 & -2.074 \\
\hline 27 & 0.0257 & 0.850 & 0.717 & 0.165 & 0.139 & 1.054 & 1.078 & 0.494 & 2 & -1.841 \\
\hline
\end{tabular}

\subsection{ANOVA for $\mathrm{S} / \mathrm{N}$ of $\mathrm{Pi}$ :}

Taguchi method combined with some multi-objective optimization methods is a good solution as it contributes to reducing the time and cost of experimentation [28]. However, if we only depended on the ranking index to find the best results and the optimal process parameters, our result will not be reliable. This is due to the fact that the number of process parameters examined by Taguchi method is the largest, but the number of experiments performed is the smallest. Therefore, the optimal process parameter in Taguchi must be determined by $\mathrm{S} / \mathrm{N}$ of ranking index. Many researchers have different options for determining optimal process parameters, some authors based on the results of the ranking index to determine optimal process parameter $[9,11]$, and other authors rely on $\mathrm{S} / \mathrm{N}$ of the ranking index to evaluate and determine optimal results [24]. Therefore, it leads to inconsistency in solving multi-objective problems. Some results have also shown that S/N of ranking index and the ranking index to determine the optimal results and its results are similar in some cases, but the results of some other problems are different. This proves that each method is only suitable for a certain type of problem. The optimal parameters will make it difficult to choose the result of the application of the techniques in production. In this study, the number of process parameters studied was 7 , and the number of experiments reviewed was only 27. In traditional optimization methods, the number of experiments required is $3^{7}$. The number of experiments performed in the Taguchi method is 81 times less than the required number. Therefore, it is necessary to determine the optima of the process parameters by $\mathrm{S} / \mathrm{N}$ of the ranking index [28]. The $\mathrm{S} / \mathrm{N}$ ratio of $\mathrm{Pi}$ in PMEDM using titanium powder is shown in Table 12.

ANOVA for $\mathrm{S} / \mathrm{N}$ of $\mathrm{Pi}$ shows that the electrode material, current and powder concentration are significant process parameters (Table 13). Other process parameters in those surveyed and interaction pairs between them were insignificant for $\mathrm{S} / \mathrm{N}$ of $\mathrm{Pi}$. The electrode material is the most significant parameter, and electrode polarity is the least significant.

Fig. 3 shows the optimal process parameter of MCDM in PMEDM using titanium powder, including SKD11, Gr (+), Ton $=20 \mu \mathrm{s}, \mathrm{I}=8 \mathrm{~A}$, Tof $=57 \mu \mathrm{s}$ and $10 \mathrm{~g} / \mathrm{l}$. The optimal process parameter determined by $\mathrm{S} / \mathrm{N}$ of $\mathrm{Pi}$ is similar to that calculated by ranking index in Taguchi-Deng's method. Only process parameters that significantly affect the $\mathrm{S} / \mathrm{N}$ of $\mathrm{Pi}$, are considered in calculation of the quality criteria at optimal conditions [38]. Therefore, the value of quality characteristics at an optimal process parameter is determined by the Eq. 17. The optimum quality characteristics were tested in Table 14, and they were correct with error $\approx 11.67 \%$.

$$
(\mathrm{MRR}, \mathrm{TWR}, \mathrm{SR}, \mathrm{HV} \text { and WLT})_{\mathrm{OPT}}=\mathrm{B}_{2}+\mathrm{E}_{3}+\mathrm{G}_{2}-2 \mathrm{~T}
$$




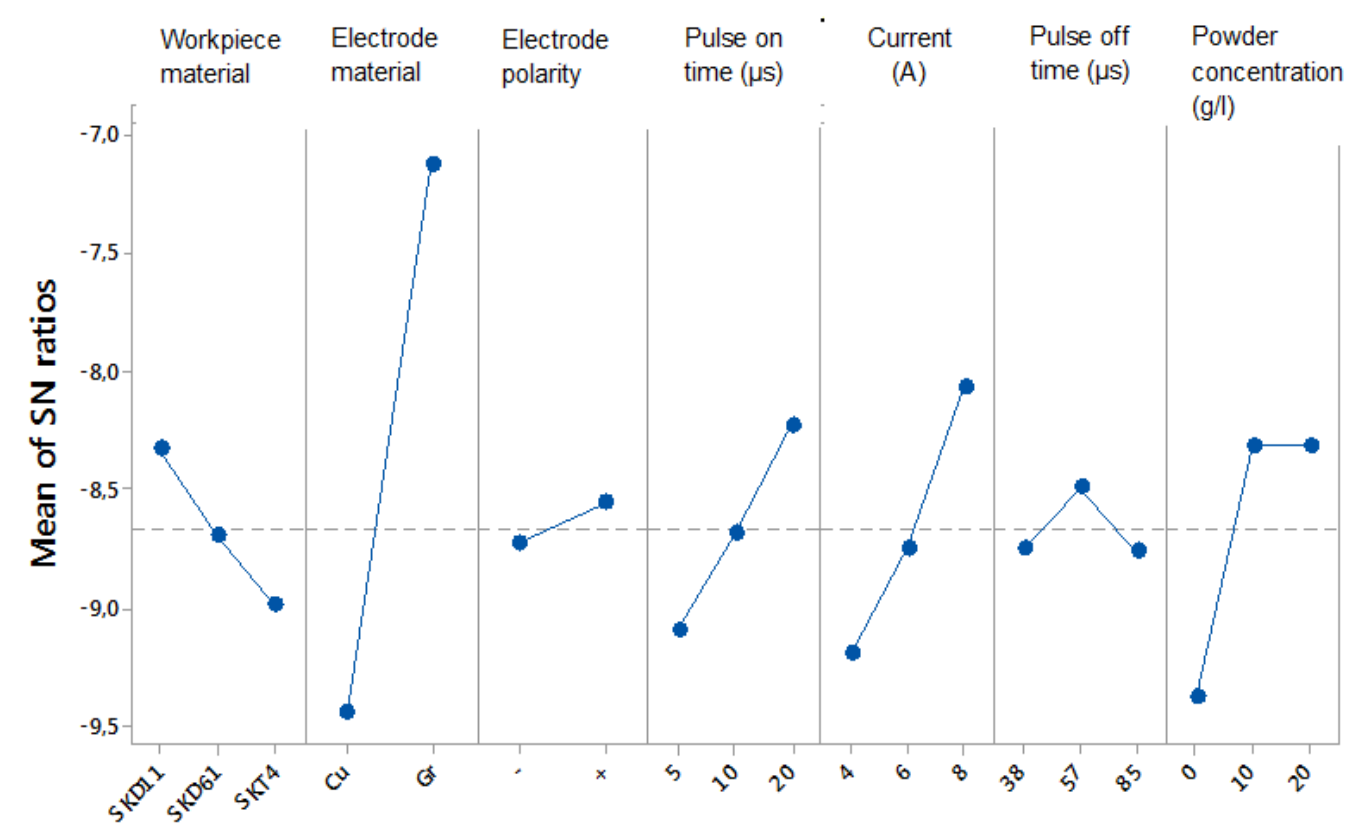

Signal-to-noise: Larger is better

Fig. 3. Process parameters effects plot for $\mathrm{S} / \mathrm{N}$ of $\mathrm{Pi}$

Table 13. Analysis of variance for $\mathrm{S} / \mathrm{N}$ ratio of $\mathrm{Pi}$

\begin{tabular}{|c|c|c|c|c|c|c|}
\hline Source & DF & Seq SS & Adj SS & Adj MS & $\mathrm{F}$ & Rank \\
\hline Workpiece material & 2 & 1.9292 & 1.4332 & 0.7166 & 1.38 & 5 \\
\hline Electrode material & 1 & 32.1156 & 32.1156 & 32.1156 & 61.87 & 1 \\
\hline Electrode polarity & 1 & 0.1729 & 0.1729 & 0.1729 & 0.33 & 7 \\
\hline Pulse on time $(\mu \mathrm{s})$ & 2 & 3.3356 & 3.3356 & 1.6678 & 3.21 & 4 \\
\hline Current (A) & 2 & 5.7797 & 5.7797 & 2.8899 & 5.57 & 2 \\
\hline Pulse off time $(\mu s)$ & 2 & 0.4135 & 0.4135 & 0.2068 & 0.40 & 6 \\
\hline Powder concentration $(\mathrm{g} / \mathrm{l})$ & 2 & 6.7902 & 7.7055 & 3.8528 & 7.42 & 3 \\
\hline $\begin{array}{l}\text { Workpiece material } \times \\
\text { Electrode material }\end{array}$ & 2 & 0.5369 & 0.5369 & 0.2684 & 0.52 & - \\
\hline $\begin{array}{l}\text { Workpiece material } \times \\
\text { Powder concentration }(\mathrm{g} / \mathrm{l})\end{array}$ & 4 & 6.8066 & 6.8066 & 1.7017 & 3.28 & - \\
\hline $\begin{array}{l}\text { Electrode material } \times \\
\text { Powder concentration }(\mathrm{g} / \mathrm{l})\end{array}$ & 2 & 1.3579 & 1.3579 & 0.6789 & 1.31 & - \\
\hline Residual Error & 6 & 3.1145 & 3.1145 & 0.5191 & - & - \\
\hline Total & 26 & 62.3527 & - & - & - & - \\
\hline \multicolumn{7}{|c|}{$\begin{array}{c}\mathrm{S}=0.72 ; \mathrm{R}-\mathrm{Sq}=95 \% ; \mathrm{R}-\mathrm{Sq}(\mathrm{adj})=78,35 \% ; \\
\quad \text { Confidence level 95\% }(\mathrm{P}=0.05)\end{array}$} \\
\hline
\end{tabular}

Table 14. Evaluate the accuracy of the optimal quality characteristics

\begin{tabular}{|c|c|c|c|c|c|c|}
\hline & \multirow{2}{*}{$\begin{array}{l}\text { Optimization } \\
\text { process } \\
\text { parameter }\end{array}$} & \multicolumn{5}{|c|}{ Quality characteristics } \\
\hline & & $\begin{array}{c}\text { MRR } \\
\left(\mathrm{mm}^{3} / \mathrm{min}\right)\end{array}$ & $\begin{array}{c}\text { TWR } \\
\left(\mathrm{mm}^{3} / \mathrm{min}\right)\end{array}$ & $\begin{array}{c}\text { SR } \\
(\mu \mathrm{m})\end{array}$ & $\begin{array}{c}\mathrm{HV} \\
(\mathrm{HV})\end{array}$ & $\begin{array}{l}\text { WLT } \\
(\mu \mathrm{m})\end{array}$ \\
\hline Calculation & \multirow{2}{*}{$\begin{array}{c}\text { SKD11, Gr(+), } \\
\text { Ton }=20 \mu \mathrm{s}, \mathrm{I}=8 \\
\text { A, Tof }=57 \mu \mathrm{s} \\
\text { and } 10 \mathrm{~g} / \mathrm{l}\end{array}$} & 53.44 & 12.65 & 4.20 & 862.56 & 9.52 \\
\hline Exp. Value & & 59.67 & 14.073 & 4.45 & 907.64 & 8.56 \\
\hline \multicolumn{2}{|c|}{ Difference (\%) } & 11.67 & 10.67 & 6.06 & 5.23 & 10.0 \\
\hline
\end{tabular}




\subsection{Comparison between improvements in preference grades using Deng's, TOPSIS, GRA and PSI:}

Deng's calculations were compared with some methods (GRA, TOPSIS, and PSI) (Table 15). The results show that TOPSIS and Deng's methods give the same result, i.e., the highest optimal efficiency at the $17^{\text {th }}$ experiment. GRA obtained best results in the $7^{\text {th }}$ experiment with the optimal process parameters SKD61, Gr $(-)$, Ton $=20 \mu \mathrm{s}, \mathrm{I}=4 \mathrm{~A}$, Tof $=57 \mu \mathrm{s}, 0 \mathrm{~g} / \mathrm{l}$. The optimal results obtained by PSI at the $14^{\text {th }}$ experiment with an optimized set of parameters are SKD11, $\mathrm{Cu}(-)$, Ton $=10 \mu \mathrm{s}, \mathrm{I}=4 \mathrm{~A}$, Tof $=85 \mu \mathrm{s}, 10 \mathrm{~g} / \mathrm{l}$. The results have shown that the methods with different data normalization steps and the value of a good and bad alternative can affect the choice of the best alternative ranking and ranking order of alternatives. It also shows that the performance of PMEDM using titanium powder has improved significantly. Moreover, Deng's result is better than the other three methods. Compared with the experimental results at the process parameters of the $1^{\text {st }}$ experiment, Deng's has the highest improvement efficiency of 56.6\%.

To evaluate the suitability of Deng's method for MCDM of PMEDM using titanium powder, a comprehensive comparison of research results with TOPSIS, GRA, and PSI have been provided in Table 16. GRA, PSI, and TOPSIS methods for the optimal process parameters obtained by ranking index are different from those method which obtain them by $\mathrm{S} / \mathrm{N}$ of ranking index. This makes it difficult to choose the set of process parameters, and it can create confusion in many optimal results [23]. In the TOPSIS method, the optimal process parameter is determined by the ranking index based on $\mathrm{S} / \mathrm{N}$ of ranking index including workpiece material, electrode polarity, pulse on time and current. In this process the electrode polarity is significant to the $\mathrm{S} / \mathrm{N}$ ratio, so the results of optimization criteria create quite significant differences. Optimal results by ranking index of GRA is insignificantly affected. This is because all three different process parameters matter in ranking index and $\mathrm{S} / \mathrm{N}$ of the ranking index, and they are insignificant for the $\mathrm{S} / \mathrm{N}$ ratio. In methods for MCDM, PSI has the least number of steps involved and is the most straightforward method. In PSI, it is not necessary to determine the weight of the quality criteria, and here the common step that is challenging is to determine the value of the weights. However, the results of the study show that powder concentration is very significant for S / $\mathrm{N}$ of ranking index of PSI. This is also one of three different parameters between the ranking index and $\mathrm{S} / \mathrm{N}$ of the ranking index to determine the optimal process parameter. This will significantly affect the difference in the value of the optimal quality criteria. Deng's method for optimal results by ranking index and $\mathrm{S} / \mathrm{N}$ of the ranking index gives similar results. Optimal results are obtained with reasonable accuracy. Therefore, it is a suitable solution to solve the multi-objective optimization of a process parameter in PMEDM using titanium powder for die steel.

Table 15. The result determines the optimal process parameter by ranking index

\begin{tabular}{|c|c|c|c|c|c|c|c|c|c|c|}
\hline \multirow[b]{2}{*}{ Method } & \multirow[b]{2}{*}{$\begin{array}{l}\text { Best } \\
\text { experi } \\
\text { ment }\end{array}$} & \multirow[b]{2}{*}{$\begin{array}{c}\text { Process } \\
\text { parame } \\
\text { ter }\end{array}$} & \multicolumn{5}{|c|}{ Quality characteristics } & \multicolumn{3}{|c|}{ Index value } \\
\hline & & & $\begin{array}{l}\text { MRR } \\
\left(\mathrm{mm}^{3}\right. \\
/ \mathrm{min})\end{array}$ & $\begin{array}{c}\text { TWR } \\
\left(\mathrm{mm}^{3} /\right. \\
\min )\end{array}$ & $\begin{array}{c}\text { SR } \\
(\mu \mathrm{m})\end{array}$ & $\begin{array}{c}\mathrm{HV} \\
(\mathrm{HV})\end{array}$ & $\begin{array}{l}\text { WLT } \\
(\mu \mathrm{m})\end{array}$ & $\begin{array}{c}1^{\text {st }} \\
\text { experi } \\
\text { ment }\end{array}$ & $\begin{array}{c}\text { Optim } \\
\text { al }\end{array}$ & $\begin{array}{c}\text { Increa } \\
\text { se } \\
(\%)\end{array}$ \\
\hline TOPSIS & $17^{\text {th }}$ & $\begin{array}{c}\text { SKD11, } \\
\operatorname{Gr}(+)\end{array}$ & & & & & & 0.389 & 0.559 & 43.7 \\
\hline Deng's & $17^{\text {th }}$ & $\begin{array}{c}\text { Ton }= \\
20 \mu \mathrm{s}, \mathrm{I} \\
=8 \mathrm{~A}, \\
\text { Tof }= \\
57 \mu \mathrm{s}, \\
10 \mathrm{~g} / \mathrm{l}\end{array}$ & $\begin{array}{c}59.66 \\
9\end{array}$ & 14.07 & 4.45 & 907.64 & 8.56 & 0.345 & 0.540 & 56.6 \\
\hline
\end{tabular}




\begin{tabular}{|c|c|c|c|c|c|c|c|c|c|c|}
\hline GRA & $7^{\text {th }}$ & $\begin{array}{c}\text { SKD61, } \\
\text { Gr(-), } \\
\text { Ton = } \\
20 \mu \mathrm{s}, \mathrm{I} \\
=4 \mathrm{~A}, \\
\text { Tof }= \\
57 \mu \mathrm{s}, 0 \\
\mathrm{~g} / \mathrm{l}\end{array}$ & 37.46 & 11.50 & 4.78 & 544.58 & 7.91 & 0.127 & 0.142 & 11.8 \\
\hline PSI & $14^{\text {th }}$ & $\begin{array}{c}\text { SKD11, } \\
\mathrm{Cu}(-), \\
\text { Ton }= \\
10 \mu \mathrm{s}, \mathrm{I} \\
=4 \mathrm{~A}, \\
\text { Tof }= \\
85 \mu \mathrm{s}, \\
10 \mathrm{~g} / \mathrm{l}\end{array}$ & 0.32 & 0.132 & 2.04 & 679.2 & 10.25 & 0.08 & 0.10 & 25 \\
\hline
\end{tabular}

Table 16. Optimal results by $\mathrm{S} / \mathrm{N}$ of ranking index

\begin{tabular}{|c|c|c|c|}
\hline $\begin{array}{c}\text { MCDM } \\
\text { methods }\end{array}$ & $\begin{array}{c}\text { Steps involved } \\
\text { (Step) }\end{array}$ & Optimal process parameter & Significant factors for S/N \\
\hline PSI & 9 & $\begin{array}{r}\text { SKT4, Gr(-), Ton }=10 \mu \mathrm{s}, \mathrm{I}=4 \mathrm{~A}, \mathrm{Tof}= \\
85 \mu \mathrm{s} \text { and } 0 \mathrm{~g} / \mathrm{l}\end{array}$ & Powder concentration \\
\hline TOPSIS & 11 & $\begin{array}{r}\text { SKT4, Gr(-), Ton }=5 \mu \mathrm{s}, \mathrm{I}=4 \mathrm{~A}, \mathrm{Tof}= \\
57 \mu \mathrm{s} \text { and } 10 \mathrm{~g} / \mathrm{l}\end{array}$ & $\begin{array}{c}\text { Electrode polarity; Powder } \\
\text { concentration }\end{array}$ \\
\hline GRA & 11 & $\begin{array}{r}\text { SKT4, Gr(+), Ton }=20 \mu \mathrm{s}, \mathrm{I}=4 \mathrm{~A}, \mathrm{Tof}= \\
85 \mu \mathrm{s} \text { and } 0 \mathrm{~g} / \mathrm{l}\end{array}$ & Powder concentration \\
\hline Deng's & 11 & $\begin{array}{r}\text { SKD11, Gr(+), Ton }=20 \mu \mathrm{s}, \mathrm{I}=8 \mathrm{~A}, \mathrm{Tof}= \\
57 \mu \mathrm{s} \text { and } 10 \mathrm{~g} / \mathrm{l}\end{array}$ & $\begin{array}{c}\text { Electrode material; Current; } \\
\text { Powder concentration }\end{array}$ \\
\hline
\end{tabular}

\subsection{The machined surface layer at the optimal process parameter:}

The optimal process parameters combination gives better performance measures with a considerable improvement in quality. In the present study, it was observed that the maximum material removal rate was obtained at optimal process parameters settings. Higher current was applied in the plasma column under higher pulse duration. It can increase spark energy which leads to higher material removal. However, the higher tool wear rate was observed since TWR was influenced by spark energy. The spark energy distribution over the machined surface due to the medium powder concentration lowered white layer thickness. Since the removal of the workpiece is higher than tool material removal, the top machined layer contained a higher amount of workpiece material [39]. Hence higher hardness has been observed at the optimal process parameters combination. Nevertheless, the average surface roughness was found due to the higher MRR. The surface finish quality at optimum conditions was compared to that after EDM, and the results showed that (i) The texture of the machined surface layer in PMEDM is more uniform than it in EDM, Fig. 4. (ii) The peak of height for surface roughness in PMEDM is smaller, however the number of peaks of surface roughness are higher. This may be because the powder mixed into dielectric fluid has formed many discharge bridges. Thus the number of sparks were increased, but the energy of the sparks was divided into many sparks, and it lead to reduction in the energy of the sparks. Besides, the machined surface after PMEDM 
has the number and the size of the adhesive particle smaller than that in EDM, Fig. 5. Powder mixed into the dielectric fluid in EDM, it led to the size of the discharge gap is increased, this allows the dielectric fluid to flush chips and powder out of the discharge gap easily. On the other hand, the energy of the sparks in the PMEDM is smaller, so the mass of evaporation and melting of the workpiece and the electrode caused by each spark was reduced. The adhesive particles on the machined surface are spherical, this is due to the pressure of the dielectric fluid which causes the surface tension, and affects the material of electrode, workpiece and titanium powder in the melting and evaporating state during EDM process [36]. White layer in PMEDM is more uniform than it is in EDM, Fig. 6. This is because the energy of sparks affects the machined surface making it more evenly distributed [40]. These results will contribute to improving the quality workpiece surface at optimum conditions.

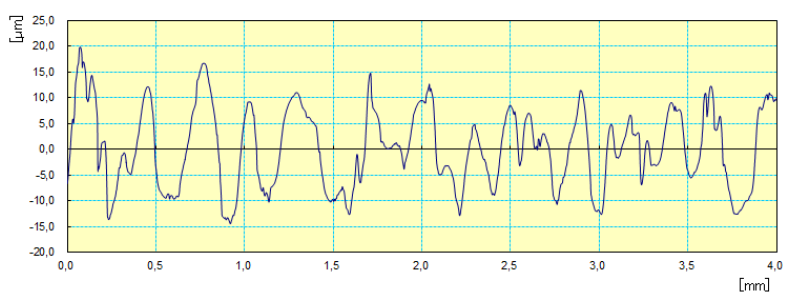

a) SKD11, $\operatorname{Gr}(+)$, Ton $=20 \mu \mathrm{s}, \mathrm{I}=8 \mathrm{~A}$, Tof $=$ $57 \mu \mathrm{s}$ and $0 \mathrm{~g} / \mathrm{l}$

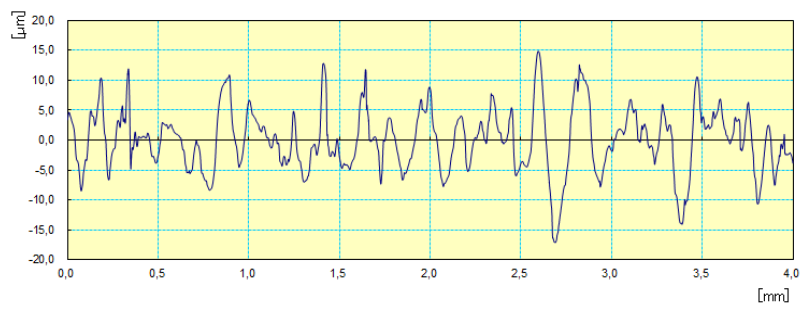

b) SKD11, Gr(+), Ton = $20 \mu \mathrm{s}, \mathrm{I}=8 \mathrm{~A}$, Tof $=$ $57 \mu \mathrm{s}$ and $10 \mathrm{~g} / \mathrm{l}$

Fig. 4. Surface texture after PMEDM

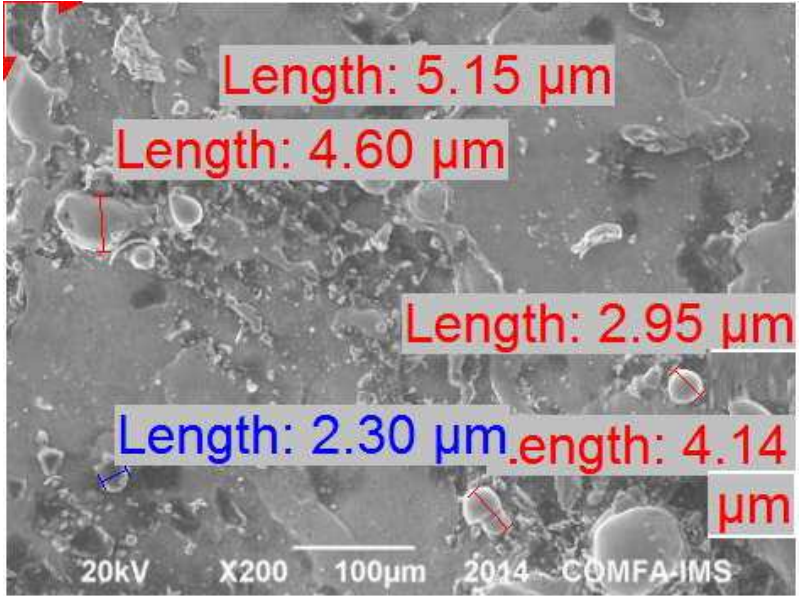

a) $0 \mathrm{~g} / \mathrm{l}$

$\left(\mathrm{d}_{\max }=5.15 \mu \mathrm{m}, \mathrm{d}_{\min }=2.3 \mu \mathrm{m}\right)$

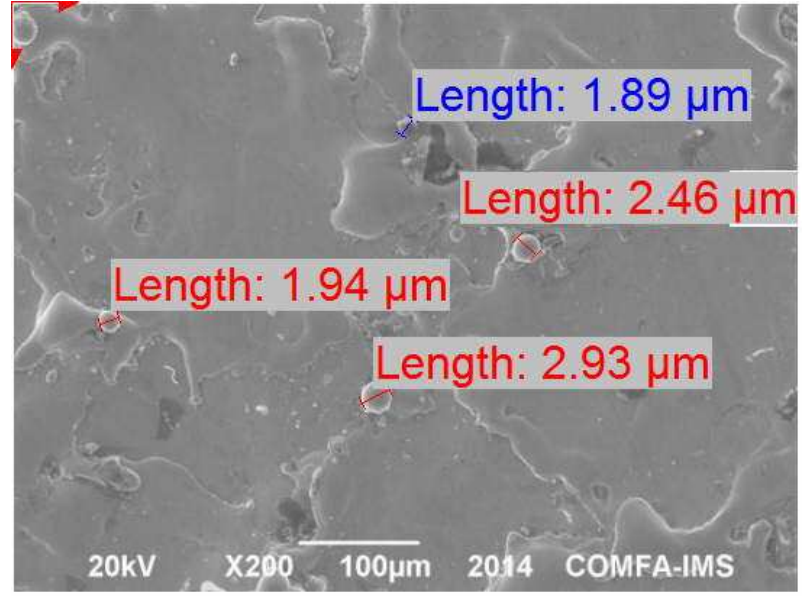

b) $10 \mathrm{~g} / \mathrm{l}$

$$
\left(\mathrm{d}_{\max }=2.93 \mu \mathrm{m}, \mathrm{d}_{\text {min }}=1.89 \mu \mathrm{m}\right)
$$

Fig. 5. Distribution and size of the adhesive particles on machined surface in PMEDM

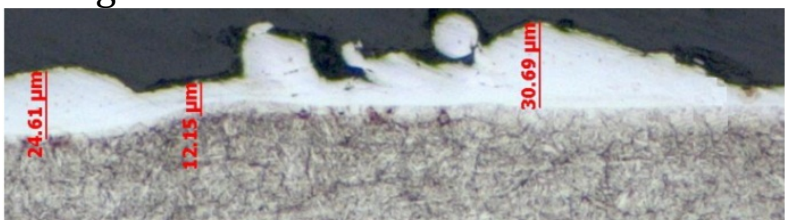

a) $0 \mathrm{~g} / \mathrm{l}$

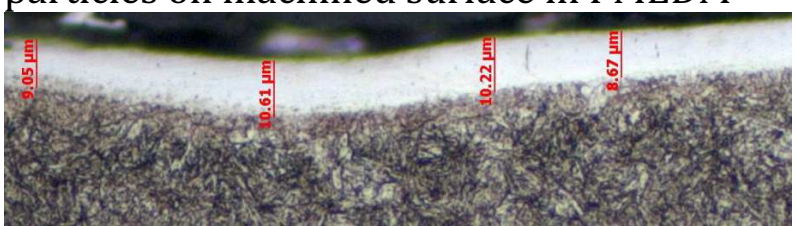

b) $10 \mathrm{~g} / \mathrm{l}$

$\left(\mathrm{WLT}_{\text {mim }}=12.15 \mu \mathrm{m}, \mathrm{WLT}_{\max }=30.69 \mu \mathrm{m}\right)$

Fig. 6. A white layer of the machined surface

(SKD11, Gr(+), Ton $=20 \mu \mathrm{s}, \mathrm{I}=8 \mathrm{~A}$, Tof $=57 \mu \mathrm{s}$ )

\section{Conclusion}

In the present study, a Deng's method-based multi-objective optimization was performed to determine a reasonable optimal solution in PMEDM with titanium powder. Based on the detailed experimental investigation, the following conclusions can be drawn: 
- Electrodes, powder concentration, current, and Ton are significant parameters for $\mathrm{Pi}$, and the level of their influence decreases, respectively. The electrode material was the most significant, having a 54.16\% level of influence. Electrodes, powder concentration, and current are the most significant parameters for optimum results, and the levels of their influence decrease in the order of $51.51 \%, 10.89 \%$, and $9.27 \%$.

- The optimal combination of input process parameters was determined to be as follows: workpiece (SKD11), electrode (Gr), electrode (positive), $\mathrm{T}_{\text {on }}(20 \mu \mathrm{s}), \mathrm{T}_{\text {of }}$ $(57 \mu \mathrm{s}), \mathrm{I}(8 \mathrm{~A})$, and powder concentration $(10 \mathrm{~g} / \mathrm{l})$ with considerably better accuracy. The optimum result was $\mathrm{MRR}=59.67 \mathrm{~mm}^{3} / \mathrm{min}, \mathrm{TWR}=14.0$ $\mathrm{mm}^{3} / \mathrm{min}, \mathrm{SR}=4.45 \mu \mathrm{m}, \mathrm{HV}=907.64 \mathrm{HV}$, and $\mathrm{WLT}=8.56 \mu \mathrm{m}$. The results have been empirically tested and found to be accurate (max error $=11.67 \%$ ).

- Electrode material, current, and powder concentration are the most influential process factors in PMEDM owing to their ability to produce spark energy during the machining process.

- PMEDM using titanium powder for die steels also produces high-quality machined surfaces at the optimum conditions. This is a technology that can effectively produce finely finished die steel moulds at reduced costs.

- Other studies have determined that the optimal set of parameters using the ranking index is not entirely appropriate. Hence, ANOVA for $\mathrm{S} / \mathrm{N}$ of the ranking index in multi-objective decision-making is essential.

- Deng's computation is the most appropriate MCDM approach in PMEDM, compared with TOPSIS, GRA, and PSI. It was shown that this combination can overcome the limitations of other methods in this area.

- The results of MCDM obtained using different methods are different; hence, a comparison between the evaluation methods in handling results is necessary, and it will help in determining the most suitable solution for improving machining productivity and quality.

Availability of data and material: Not applicable

Competing interests: Not applicable

Funding: Not applicable

Authors' contributions: Phan Nguyen Huu experimented and built the manuscript structure.

\section{Acknowledgments}

This research is funded by the Vietnam National Foundation for Science and Technology Development (NAFOSTED) under grant number “107.01-2017.303”.

\section{Authors' information (optional): Not applicable}

\section{References}

1. Mohd N, Darius A, Solomon G and Bahari MF. A review on current research trends in electrical discharge machining (EDM). International Journal of Machine Tools and Manufacture. 2007; 47; 1214-1228. 
2. Tripathy S and Tripathy DK. Surface Characterization and Multi-response optimization of EDM process parameters using powder mixed dielectric. Materials Today: Proceedings 2017; 4; 2058-2067.

3. Tang L and Du YT. Experimental study on green electrical discharge machining in tap water of Ti-6Al-4V and parameters optimization. The International Journal of Advanced Manufacturing Technology 2014; 70; 469-475.

4. Vijay KM and Man SA. Micro-EDM multiple parameter optimization for $\mathrm{Cp}$ titanium. The International Journal of Advanced Manufacturing Technology 2017; 89; 897 - 904.

5. Rajiv KS and Jagdeep S. Determination of multi-performance characteristics for powder mixed electric discharge machining of tungsten carbide alloy, ProcIME Part B: Journal of Engineering Manufacture 2014; 230; 303-312.

6. Tripathy $S$ and Tripathy DK. Multi-response optimization of machining process parameters for powder mixed electro-discharge machining of H-11 die steel using grey relational analysis and topsis. Journal Machining Science and Technology An International Journal 2017; 21; 362-384.

7. Prabhu S and Vinayagam BK. Multiresponse optimization of EDM process with nanofluids using TOPSIS method and Genetic Algorithm. Archive of Mechanical Engineering 2016; 63; 45-71.

8. Sivapirakasam SP, Mathew J and Surianarayanan M. Multi-attribute decision making for green electrical discharge machining. Expert Systems with Applications 2011; 38; 83708374.

9. Durairaj M, Sudharsun D and Swamynathan N. Analysis of Process Parameters in Wire EDM with Stainless Steel using Single Objective Taguchi Method and Multi Objective Grey Relational Grade. Procedia Engineering 2013; 64; 868 - 877.

10. Muthuramalingam $\mathrm{T}$ and Mohan B. Application of Taguchi-grey multi responses optimization on process parameters in electro erosion, Measurement 2014; 58; 495-502.

11. Tiwary AP, Pradhan BB and Bhattacharyya B. Application of multi-criteria decision making methods for selection of micro-EDM process parameters. The International Journal of Advanced Manufacturing Technology 2014; 2; 251-258.

12. Dewangan S, Gangopadhyay S and Biswas CK. Study of surface integrity and dimensional accuracy in EDM using Fuzzy TOPSIS and sensitivity analysis, Measurement 2015; 63; 364-376.

13. Diyaley S, Shilal P, Shivakoti I, Ghadai RK and Kalita K. PSI and TOPSIS Based Selection of Process Parameters in WEDM, Periodica Polytechnica Mechanical Engineering 2017; 61; 255-260.

14. Petković D, Madić M, Radovanović M and Gečevska V. Application of the performance selection index method for solving machining mcdm problems, Mechanical Engineering 2017; 15; $97-106$.

15. Gadakh VS. Parametric Optimization of Wire Electrical Discharge Machining Using TOPSIS Method. Advances in Production Engineering \& Management 2012; 7; 157-164.

16. Das PP, Gupta P, Das S, Pradhan BB and Chakraborty S. Application of grey-fuzzy approach in parametric optimization of EDM process in machining of MDN 300 steel, Materials Science and Engineering 2017; 297; 1-8.

17. Tripathy $S$ and Tripathy DK. Multi-attribute optimization of machining process parameters in powder mixed electro-discharge machining using TOPSIS and grey relational analysis. Engineering Science and Technology, an International Journal 2016; 19; 62-70.

18. Dastagiri M, Rao PS and Valli PM. TOPSIS, GRA Methods for Parametric Optimization on Wire Electrical Discharge Machining (WEDM) Process. All India Manufacturing Technology, Design and Research Conference 2016; 497-504.

19. Muniappan A, Jaivaakheish AP, Jayakumar V, Arunagiri A and Senthilkumar R. Multi objective optimization of process parameters in WEDM of aluminum hybrid composite using taguchi and TOPSIS techniques. Materials Science and Engineering 2018; 402; 1-10. 
20. Raj SON and Prabhu S. Analysis of multi objective optimisation using TOPSIS method in EDM process with CNT infused copper electrode. Int. J. Machining and Machinability of Materials 2017; 19; 76-94.

21. Khanna R, Kumar A, Garg MP, Singh A and Sharma N. Multiple performance characteristics optimization for Al 7075 on electric discharge drilling by Taguchi grey relational theory. Journal of Industrial Engineering International 2015; 11; 459-472.

22. Manivannan R and Kumar MP. Multi-attribute decision-making of cryogenically cooled micro-EDM drilling process parameters using TOPSIS method. Journal Materials and Manufacturing Processes 2017; 32; 209-215.

23. Behera SU. Application of fuzzy logic and TOPSIS in the taguchi method for multiresponse optimization in electrical discharge machining (EDM). Bachelor of Technology In Mechanical Engineering, National institute of technology 2012.

24. Kumaran ST, Ko TJ and Kurniawan R. Grey fuzzy optimization of ultrasonicassisted EDM process parameters for deburring CFRP composites. Measurement 2018; $123 ; 203-212$.

24. Naik DK, Khan A, Majumder $\mathrm{H}$ and Garg RK. Experimental Investigation of the PMEDM of Nickel Free Austenitic Stainless Steel: A Promising Coronary Stent Material. Silicon 2019; $11 ; 899-907$.

25. Namdev V, Singh AK, Patidar P and Pradhan MK. Multi-criteria Decision Making for the Optimization of Machining Process Parameters in EDM. Proceedings of 1st International Conference on Mechanical Engineering: Emerging Trends for Sustainability 2014; 343-350.

26. Abidi MH, Ahmari AMA, Umer U and Rasheed MS. Multi-objective optimization of micro-electrical discharge machining of nickel-titanium-based shape memory alloy using MOGA-II. Measurement 2018; 125; 336-349.

27. Tansel YI, Dengiz B and Dengiz O. TOPSIS based Taguchi method for multi-response simulation optimization of flexible manufacturing system. Proceedings of Winter Simulation Conference 2014; 2147-2155.

28. Atul S, Pankaj A and Rana RS. Applications of TOPSIS Algorithm on various Manufacturing Processes: A Review. Materials Today: Proceedings 2017; 4; 5320-5329.

29. Muniappan A, Jaivaakheish AP, Jayakumar V, Arunagiri A and Senthilkumar R. Multi objective optimization of process parameters in WEDM of aluminum hybrid composite using taguchi and topsis techniques. Materials Science and Engineering 2018; 402; 1-10.

30. Nayak B. Multi-Response Optimization in Machining: Exploration of TOPSIS and Deng's Similarity Based Approach. Master of Technology (M. Tech.), National institute of technology - India 2016.

31. Prabhu S and Vinayagam BK. Multiresponse optimization of edm process with nanofluids using Topsis method and Genetic algorithm. Archive of me chanical engineering 2016; LXIII; 45-71.

32. Manivannan R and Kumar MP. Multi-response optimization of Micro-EDM process parameters on AISI304 steel using TOPSIS. Journal of Mechanical Science and Technology 2016; 30; 137-144.

33. Montenegro LV, Puig AB and Coque JMG. Multi-Criteria Methodology: AHP and Fuzzy Logic in the Selection of Post-Harvest Technology for Smallholder Cocoa Production. International Food and Agribusiness Management Review 2014, Vol. 17( 2), 2014, 107-124.

34. Babu KA, Venkataramaiah P and Dileep P. AHP-DENG'S Similarity Based Optimization of WEDM Process Parameters of Al/SiCp Composite. American Journal of Materials Science and Technology 2017; 6; 1-14.

35. Khan AM, Ning H, Liang L and Jamil M. Comment to paper entitled "Experimental investigation of machinability characteristics and multiresponse optimization of end milling in aluminium composites using RSM based grey relational analysis" Measurement 105(2017) 78-86; Measurement 2018; 119; 175-177. 
36. Peças $P$ and Henriques E. Effect of the powder concentration and dielectric flow in the surface morphology in electrical discharge machining with powder-mixed dielectric. The International Journal of Advanced Manufacturing Technology 2008; 37;1120-1132.

37. Saaty TL. Decision making with the analytic hierarchy process, Int. J. Services Sciences 2008; 1 ; 83-98.

38. Roy RA. Primer on the Taguchi Method. New York: Van Nostrand Reinhold 1990.

39. Shahri HRF, Mahdavinejad R, Ashjaee M and Abdullah A. A comparative investigation on temperature distribution in electric discharge machining process through analytical, numerical and experimental methods. International Journal of Machine Tools and Manufacture 2017; 114; 35-53.

40. Muthuramalingam T. Measuring the influence of discharge energy on white layer thickness in electrical discharge machining process. Measurement 2019; 131; 694-700.

\section{Nomenclature}

MRR Material removal rate $\left(\mathrm{mm}^{3} / \mathrm{min}\right)$

TWR Tool removal rate $\left(\mathrm{mm}^{3} / \mathrm{min}\right)$

EWR Relative tool wear ratio is the ratio of TWR and MRR (\%)

HV Micro- Hardness of machined surface (HV)

SR Surface roughness $(\mu \mathrm{m})$

CS Cutting Speed ( $\mathrm{mm} / \mathrm{min})$

DD Dimensional Deviation (mm)

OC Overcut (mm)

TA Taper angle (rad)

$\mathrm{C}_{\mathrm{ent}} \quad$ Circularity at the entry

$\mathrm{C}_{\text {exit }} \quad$ Circularity at the exit

Kerf Kerf Width (mm)

WF Wire feed rate $(\mathrm{mm} / \mathrm{min})$

GV Gap voltage (V)

Ton Pulse on time $(\mu s)$

Tof Pulse off time $(\mu \mathrm{s})$

I Current (A)

$\mathrm{T}_{\mathrm{up}} \quad$ Tool lift time(s)

$\mathrm{T}_{\mathrm{w}} \quad$ Tool work time(s)

Tau Duty cycle (\%)

Wt Wire Type

S Sensitivity $(\mathrm{mm} / \mathrm{min})$

W.T Wire tension(grm)

FP Flushing pressure $\left(\mathrm{kg} / \mathrm{cm}^{-2}\right)$

$\mathrm{SF} \quad$ Servo feed rate $(\mathrm{mm} / \mathrm{min})$

D Fractal dimension (mm)

F $\quad$ Frequency (Hz)

WLT White layer thickness $(\mu \mathrm{m})$

SCD surface crack density $\left(\mu \mathrm{m} / \mu \mathrm{m}^{2}\right)$

$\mathrm{T} \quad$ Process time (s)

E Process energy (W)

$\mathrm{C}_{\mathrm{A}} \quad$ Concentration of aerosols $\left(\mathrm{mg} / \mathrm{m}^{3}\right)$

DC Dielectric consumption $\left(\mathrm{cm}^{3}\right)$ 
TOPSIS Technique for order preference by similarity to ideal solution

GRA Grey relational analysis

PSI Performance selection index

RSM Response surface method

Deng's Deng's similarity-based method

AHP Analytic Hierarchy Process

SDV Standard Deviation

PCA Principal component analysis

EDM Electrical discharge machining

PMEDM Powder mixed electrical discharge machining

ANOVA Analysis of Variance

S/N Signal-to-noise

MCDM Multi - criteria decision making 
Figures

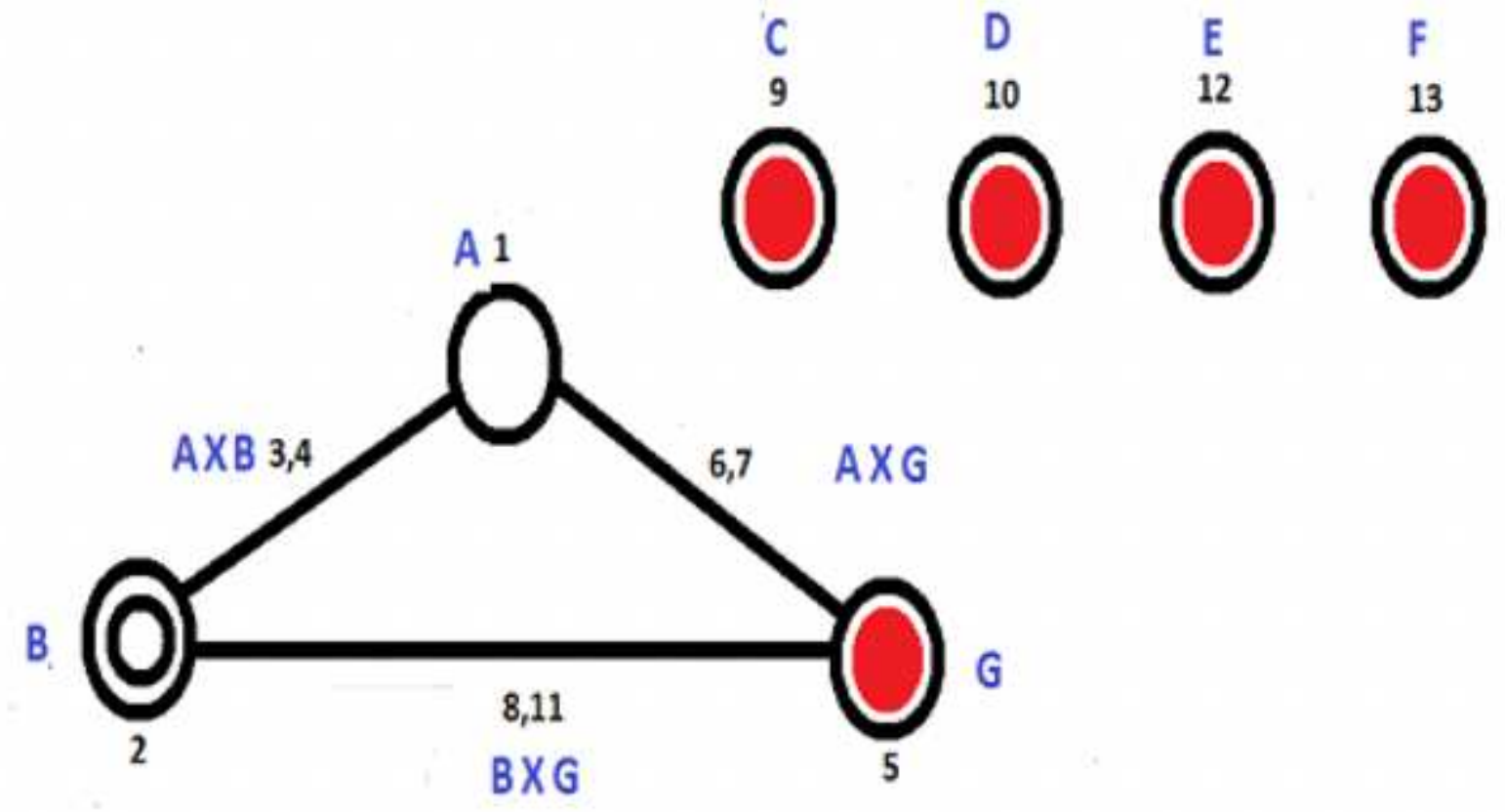

Figure 1

Scheme assign objects for L27 orthogonal array with dummy treat [38]

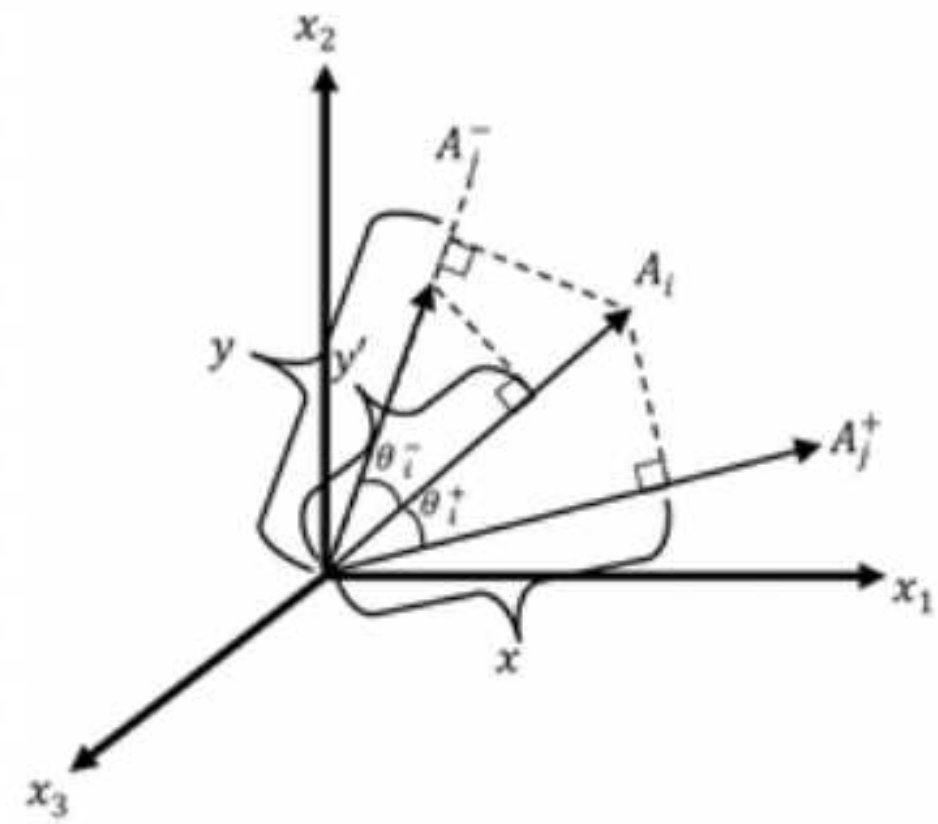

Figure 2

The degree of conflict between alternatives and $\mathrm{Aj}+(\mathrm{Aj}-)$ [28]. 


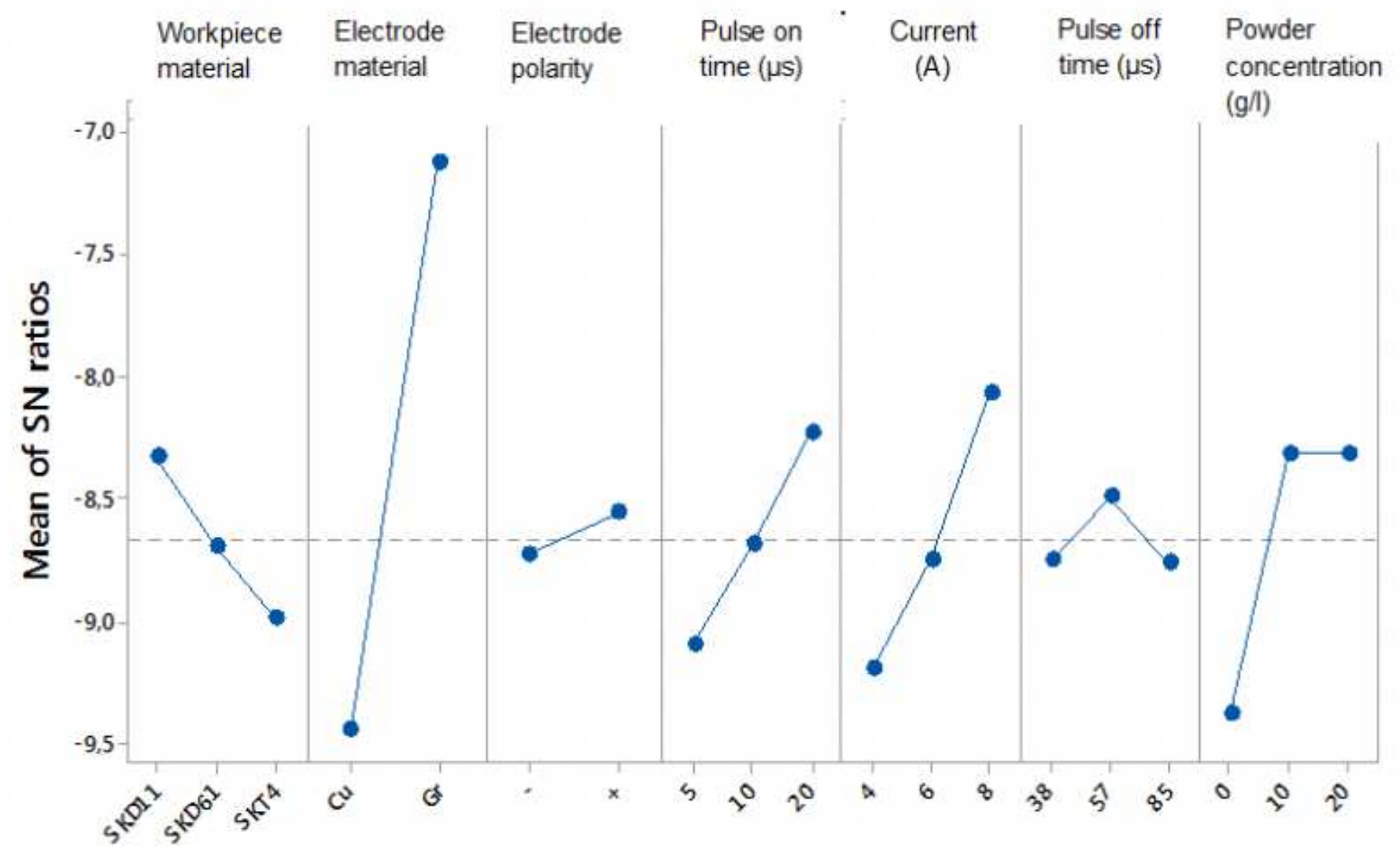

Signal-to-noise: Larger is better

\section{Figure 3}

Process parameters effects plot for $\mathrm{S} / \mathrm{N}$ of $\mathrm{Pi}$

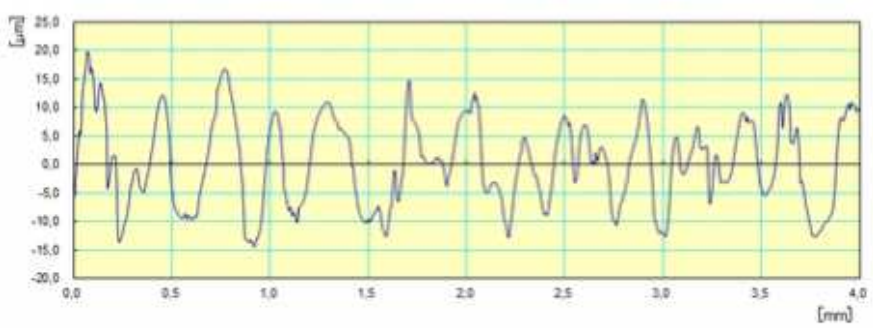

a) SKD11, Gr(+), Ton $=20 \mu \mathrm{s}, \mathrm{I}=8 \mathrm{~A}$, Tof $=$ $57 \mu$ s and $0 \mathrm{~g} / \mathrm{l}$

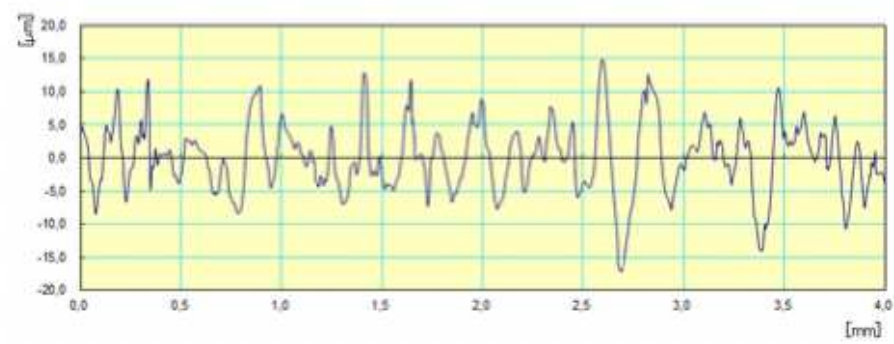

b) SKD11, Gr(+), Ton = $20 \mu \mathrm{s}, \mathrm{I}=8 \mathrm{~A}$, Tof $=$ $57 \mu \mathrm{s}$ and $10 \mathrm{~g} / \mathrm{l}$

Figure 4

Surface texture after PMEDM 


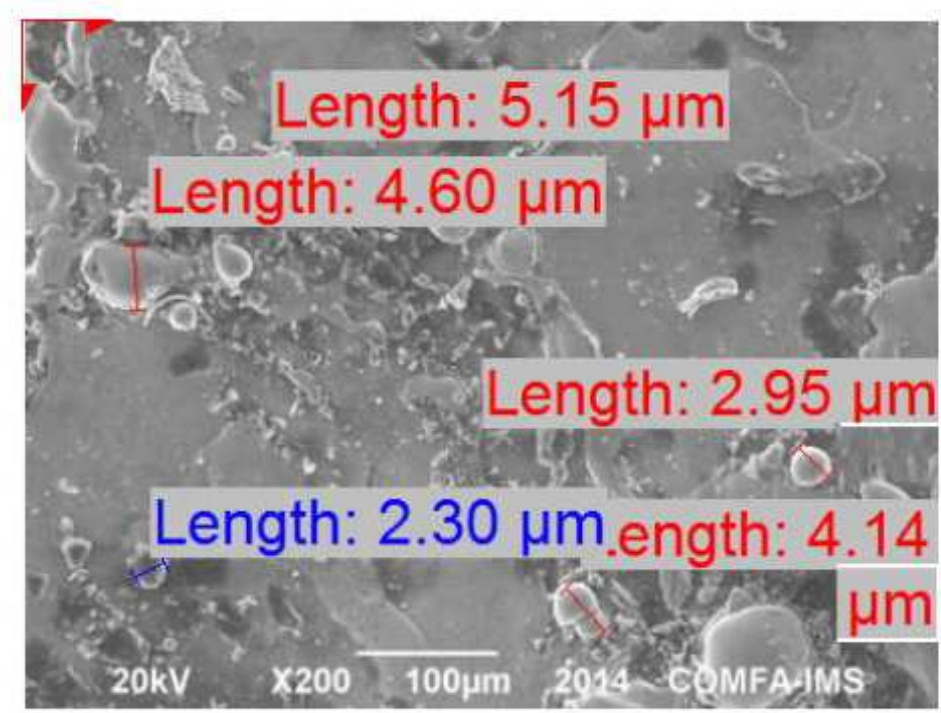

a) $0 \mathrm{~g} / \mathrm{l}$

$\left(\mathrm{d}_{\max }=5.15 \mu \mathrm{m}, \mathrm{d}_{\min }=2.3 \mu \mathrm{m}\right)$

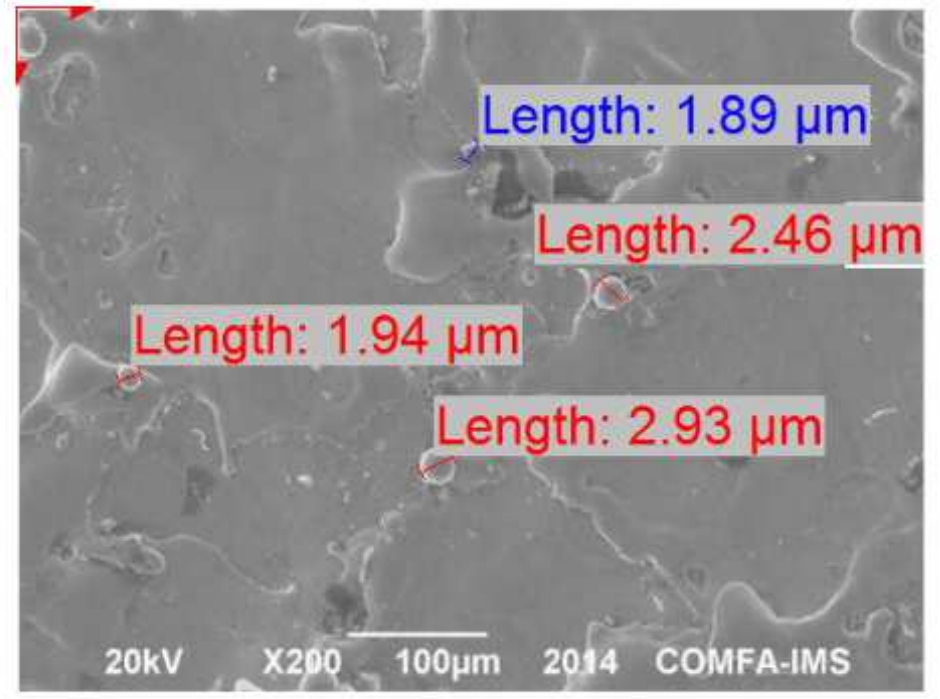

b) $10 \mathrm{~g} / \mathrm{l}$

$$
\left(\mathrm{d}_{\max }=2.93 \mu \mathrm{m}, \mathrm{d}_{\min }=1.89 \mu \mathrm{m}\right)
$$

\section{Figure 5}

Distribution and size of the adhesive particles on machined surface in PMEDM

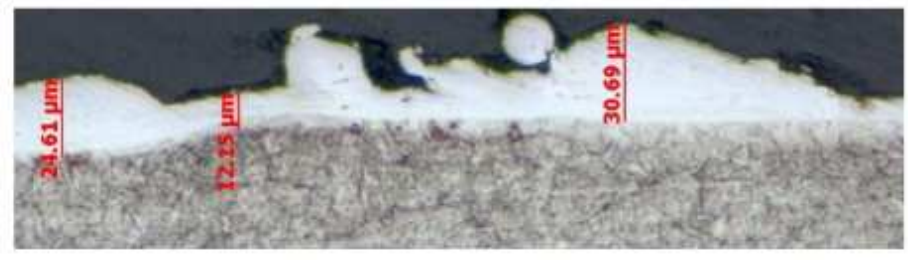

a) $0 \mathrm{~g} / \mathrm{l}$

$\left(\mathrm{WLT}_{\operatorname{mim}}=12.15 \mu \mathrm{m}, \mathrm{WLT}_{\max }=30.69 \mu \mathrm{m}\right)$

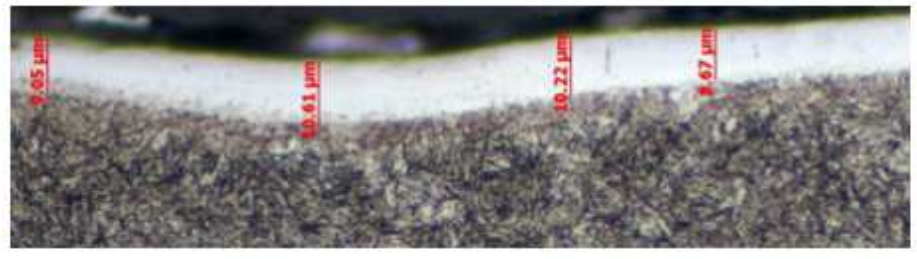

b) $10 \mathrm{~g} / \mathrm{l}$

$\left(\mathrm{WLT}_{\min }=8.67 \mu \mathrm{m}, \mathrm{WLT}_{\max }=10.61 \mu \mathrm{m}\right)$

Figure 6

A white layer of the machined surface. (SKD11, Gr(+), Ton $=20 \mu \mathrm{s}, \mathrm{I}=8 \mathrm{~A}$, Tof $=57 \mu \mathrm{s})$ 